原著

\title{
アパタイト表面における骨組織形成ならびに その石灰化について
}

\author{
小木曾誠

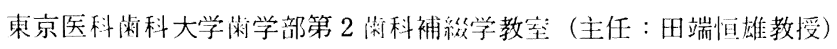

(1982年10月18日 受付)

\section{Formation and Calcification of BoneTissue on the Surface of Apatite Ceramics}

\author{
Makoto Ogiso \\ The 2nd Department of Prosthodontics Faculty of Dentistry Tokyo Medical and Dental University \\ (Director: Prof. Tsuneo Tabata)
}

Apatite implantation into the jaw bones of adult dogs was carried out histologically to check the biocompatibility.

At 5 days, the bone matrix formation began on the surface of the apatite. In the 10-day specimen, the area of bone formation on the surface of the apatite was enlarged and at the same time the calcification began.

TEM observation of this condition revealed the differentiation of the osteoblast around the surface of the apatite, followed by the formation of collagen fibers and osteoid with many small round deposits of bone crystals and matrix vesicles in an isolated from.

A thin layer without the collagen fibers was observed on the surface of the apatite. In such areas, the plate-shaped crystals began to deposit directly on the surface of the apatite.

In the area where the bone formation was rapid at 10 days, gradually the isolated crystal deposits became larger by the further deposition of crystals in the longitudinal direction to the surrounding collagen fibers and fused with each other, and fused further with the crystal layer without the collagen fibers on the surface of the apatite. Finally, a wide calcified layer was formed on the apatite.

Subsequently, the crystals on and around the apatite grew gradually and exhibited a condition similar to that of the normal mature bone at 30 days.

\section{1. 緒言}

歯の欠損部に人工の歯を植立し，それに天然芷 の機能を代行させよらとするデンタル・インプラ ントに関して，かなり古くから多くの研究者によ ってさまざまな材料が用いられ，さらにそのデザ インをも含めて研究がなされてきた。
今世紀半ばにいたり，材料の加工性および物性 の問題に加え, 生体組織内での安定性ならびに親 和性に重点がおかれるよらになった。以来，金 属, 合成樹脂, 七ラミックスなど多くの材料につ いて, 組織との親和性に閔し研究がなされてきて いる。

著者は, 顎骨内に埋入されたデンタル・インプ 
ラントが，周国骨組織によって強固に扎持される ためには、イン・ラント体が骨組織に対して無青 であることにとどまらず，骨組織と直接結合する ことが必要な条件であると考えている。

今日までインプラント材料として研究の対象と なってきた多くの材料の中で以上のような条件を そなえた材料は, Bioglass ${ }^{1-4)}$, glassceramics ${ }^{5,6)}$, $\mathrm{TCP}^{7-9)}$, apatite ceramics ${ }^{10-18)} の 4$ 種類りン酸 カルシウム系七ラミック材のみにしぼられる。

著者は生体硬組織を構成する無機質の主成分で あるアパタイトをデンタル・インプラント材料と して用いれば，免疫反応を起こさずに高い組織親 和性が得られるのではないかと考え, アパタイト を材料としたデンタル・インプラントの開発を企 てた。

まず，1978年顎骨内に埋入したアパタイト周囲 の骨組織形成に関して，主として光学顕微鏡を用 いて経時的変化の観察を行った ${ }^{10)}$ 。この結果に基 づきアパイト・デンタル・インプラントに関し てさらに種々の研究を積又重补11,12), 現在臨床的 に応用する段階にいたっている12-14)。

今回は著者が観察を行ってきた光学顕微鏡所見 とともに、アパタイト表面に形成される骨組織の 形成過程，とくにアハタイト表面上に打领組 織の結晶沈着状態について, 透過電子顕微鏡を用 いて観察を行った結果を報告する。

\section{2. 研究材料および研究方法}

埋入材料として焼結性が異なる相対密度56〜99 $\%$ の synthetic hydroxy apatite ceramics (旭光 学社製, 図16, 以下アハタイトと記載する) を, 直径 $4.7 \mathrm{~mm}$, 長さ $8 \sim 10 \mathrm{~mm}$ の円筒形に形成し たものを使用した。

実験動物には成犬を用い, 下顎第 4 小田歯およ び第 1 大臼歯を抜去， 3 力月後抜歯した部位の粘 膜を剥離し，顎骨に歯慒頂側から直径 $5.0 \mathrm{~mm}$ の ドリルで片側に 3 個の穴をあけ，それに前述のア ハタイトをそ机ぞれ1個，アハタイト上縁が骨表 面之一致するように埋入し，粘膜縫合を行った。

埋入後 3〜410日経過したのち，アパタイト上
部表面に形成された軟組織や骨組織を除去し，生 理食塩水注水下で歯科用分ヤヤンドディスクを 用いて, アパタイトの隅角部を顎骨組織とともに 幅約 $1 \mathrm{~mm}$ のクサビ状に切断し, 電子頙微鏡用観 察䧣本とし, 残部を光学顕微鏡用観察標本として 用いた。

電子顕微鏡用観察慓本は $5 \%$ glutaraldehyde および $2 \% \mathrm{O}_{\mathrm{s}} \mathrm{O}_{4}$ の二重固定を行い, Epon 812包 埋後末脱灰のままダイヤモンドナイフを用いて 超薄切片を作製した。それらの切片を一部は無 染色のまま, 一部は uranylacetate および lead hydroxide の二重染色を行ったのち，電子顕微 鏡を用いて観察を行った。

光学顕微鏡用観察標本は $10 \%$ ホルモールアルコ ールで固定後, 一部は脱灰七ロイジン包埋した後 約 $10 \mu \mathrm{m}$ の煩舌断連続切片を作製し，へマトキシ リン・エオジン染色を施した。一部は未脱灰のま まりゴラック包埋を行い, アパタイトと顎骨組織 を含む約 $100 \mu \mathrm{m}$ の横率薄切切片を作製し、トル イジン・ブルー染色を施して観察を行った。

\section{3. 結 果}

\section{1. 埋入後 3 日および 5 日}

埋入後 3 日では, アパタイトと埋入時ドリルに よって切削された顎骨組織との間隙ではほとんど 組織分化が進行しておらず, アハタイト周囲に骨 組織の形成は全く認められない。しかしながら， 埋入時ドリルによって切削された骨梁の切断面に 隣接する骨梁表面およびその近傍においては, 骨 芽細胞が分化を起こし骨組織の形成が開始されて いる(図17)。

埋入後 5 日にいたると, アバタイト周罒での組 織分化が進行し，とくにアハタイトが海綿質に埋 入されている領域では, 元将の骨梁周囲から幼若 な新牛骨梁がアパタイト表面に向かって毛細血管 をさけつつ, 網目状に形成されるようになる（図 18)。

これらの 新生骨梁はところどころでアパタイ 卜表面に達している。さらにこの接触部位を中心 として，アハタイト表面で骨芽細胞が分化を起こ 
し，骨組織の形成が開始されている領域も観察さ れる(図19)。これらアハタイト表面およびその近 傍に形成されている新生骨組織は, トルイジン・ ブルーによって薄青く染色され，骨基質を構成す る膠原線維の密度が低く, 石灰化も開始されてい ない幼若な骨組織であることが羿められる。

アハタイト表面に形成された骨組織を透過電子 顕微鏡で観察すると，骨芽細胞によって形成され た collagen 線維の密度は, 通常の骨前質におけ る collagen 線維のそれに比していまだかなり粗 な状態であり，とくにアハタイト表面においては その近傍に比して collagen 線維の密度が低い （図 1)。このようなアパタイト表面周朋に形成さ れている骨基質にはいまだ結晶の沈着は認められ ない。

また顎骨内に埋入されたアパタイトの焼結性が 低く相対密度が低い場合には，アパタイト表面に 多核の破骨細胞が出現しているのが観察される (図20)。このよらな破骨細胞を透過電子顕微鏡で 観察すると, 微細なアバタイトの結晶粘をとりこ んでいるのが認められる。

\section{2. 埋入後10日}

アハタイトと元来の顎骨組織との間隙に打ける 骨組織の形成は，埋入後 5 日に比してさらに進行 ナるとともにその形成籁围も拡大され, 緻密質領 域・海綿質域のいずれにおいても，アパタイト周 网に網目状の骨梁が密に形成された状態となる。 それに伴いアハタイトの表面に拈ける骨組織の形 成も進行し，とくに焼結性の高いア，タイトの場 合には，緻密質領域・海綿質領域ともにその表面 のほぼ全域に骨組織の形成が認められる(四21)。 また焼結性の低いアパタイトの場合に沶いても， アパタイト表面に骨組織の形成範囲が 拡大する が，多核の細胞丮数多くその表面に出現してい る。これらのアハタイト周囲の新生骨梁, および アパタイト表面に形成されてた新生肖組織は，埋入 後5日で認められたそれに比して幅がかなり広く 発育している。

アハタイト表面に形成さ机ている新生骨組織の トルイジン・ブルーに対する染色性は, 部位によ りかなりの差異が認められる(敦2，23）。一般 的には赤紫色に異調染色される骨組織が多いが,

一部には青く染色される部分，また青く染色され る骨基質中に，赤紫色に異調染色される小さな顆

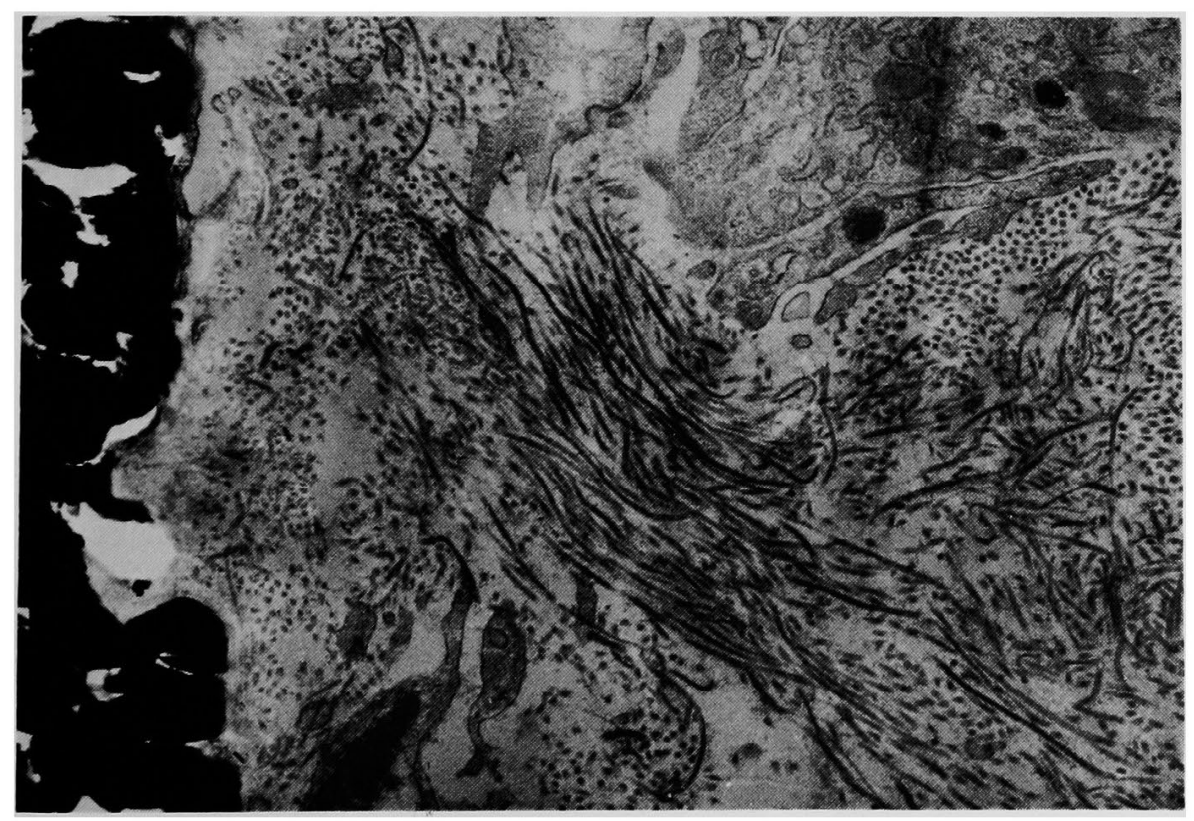

図 1 アパタイト表面近傍で骨基質の形成が始まっている $(\times 16,800)$ 
粒状構造物が多数混在している部分なども観察さ れる。アバタイト表面に形成された骨基質中に異 調染色される槛造物が出現する際，まずアパタイ 卜表面上に出現し始め, 順次骨芽細胞の方に向か って挔大していく。

アパタイト表面に形成された骨組織を透過電子 顕微鏡で観察すると， アパタイト表面には collagen 線維が密に配列した幅広い層が形成されて おり(図2)，その層の中でもアパタイト近傍では collagen 線維間に結晶が群集をなして沈着して いる状態が観察される(図 3 )。それらは大小さま ざまな円形をなし島状に多数出現している。個々 の結晶群は, 細長い板状結晶により構成されてお り, 板状結晶の配列には規則性はない。また結晶 沈着周囲には限界膜が部分的に認められるものも 多い。さらに collagen 線維間にさまざまな大き さの基質小胞が存在している(図14)。これらの基 質小胞内には結晶沈着が認められるものと涩めら れないものとがある。結晶が認められない基質小 胞の内部は, 一椂に電子密度が高い構造からなる ものや, 電子密度が高い部分と低い部分とが混在 するものなど種々な状態が観察される。アパタイ 卜表面近傍の骨基質内にこのよらな結晶沈着が開 始されると、アパタイト表面においても細長い板 状結晶が直接形成され始めている(図 3，5)。了 パタイト表面を詳細に観察すると, アハタイト表 面の collagen 線維は周囲に比べて一般に粗な状 態となっており，なかには collagen 線維が達し ていない部分もみられる。アパタイト表面に結晶 が直接形成され始めている時期では, アパタイト 表面近傍の collagen 線維形成領域において，前 述のよらな結晶沈着が認められる以外にいまだ collagen 線維に沿った結晶沈着はほとんど観察 されない。すなわちアパタイト表面では, collagen 線維に沿って結晶沈着が生ずる以前に, collagen 線維とは関係なく結晶が形成されてい る。

またアパタイトの焼結性が低く相対密度が低い 場合には, アパタイト表面に多数の小孔がみら れ，そのアハタイト表面から内部に位置する小孔
内においても，小孔壁に沿って細い板状結晶が形 成されている(図6)。この際これら内部の小孔内 には, 一般に collagen 線維の形成はみられな い。

上記の状態より石灰化がさらに進行している領 域では, 骨基質内において島状に多数存在する結 晶沈着を中心として周囲 collagen 線維に沿った 結晶沈着が進行するよらになり, 隣接の結晶沈着 領域之順次融合し結晶の沈着領域が拡大してい る。それらはやがてアパタイト表面を基盤とした 結晶の沈着層とも連続した状態となる(図 6 )。

以上のよらな状態で埋入後10日において骨形成 が早く進行している領域では、アパタイト表面に かなり幅広い石灰化層が形成されている(図 7 )。 しかしこの時期で江骨組織 の石灭化が最も克進 している部位でも，骨結晶恃成熟骨のそれに比べ て細く短く、いまだ幼若な発育状態である（図 $8)$ 。

またアパタイト表面では，結晶の形成開始時期 に比べて結晶密度が著しく増大し, それらの結晶 沈着が周囲の骨組織とは異なり均質な状態で観察 される部位も認められる(図 8)。このアパタイト 表面に形成された結晶層の幅は, 必ずしも一定し ているとは限らず，注とんど認められない領域か ら約 $0.2 \mu \mathrm{m}$ に及ぶ領域も観察される。

\section{3. 埋入後14日}

アパタイトと元来の顎骨組織との間隙における 骨組織の形成は, 埋入後10日に比してさらに進行 した状態となる。新生された骨組織は,トルイジ ン・ブルーによる染色性が減少していることか ら，石灰化がかなり進行していることがうかがえ る(図24)。

また埋入後14日にいたると，アパタイトが緻密 質と海綿質に埋入されている領域とでは，アパタ イト周囲に怙ける骨組織形成の進行度が異なって くる。すなわちアパタイトが緻密質に埋入されて いる領域では，すでに細い血管を中心としたハバ 一ス層板の形成が各所で開始されている。またこ の領域に形成されている骨組織表面には, 幅広い 骨前質ならびに密に配列した骨芽細胞が観察さ 


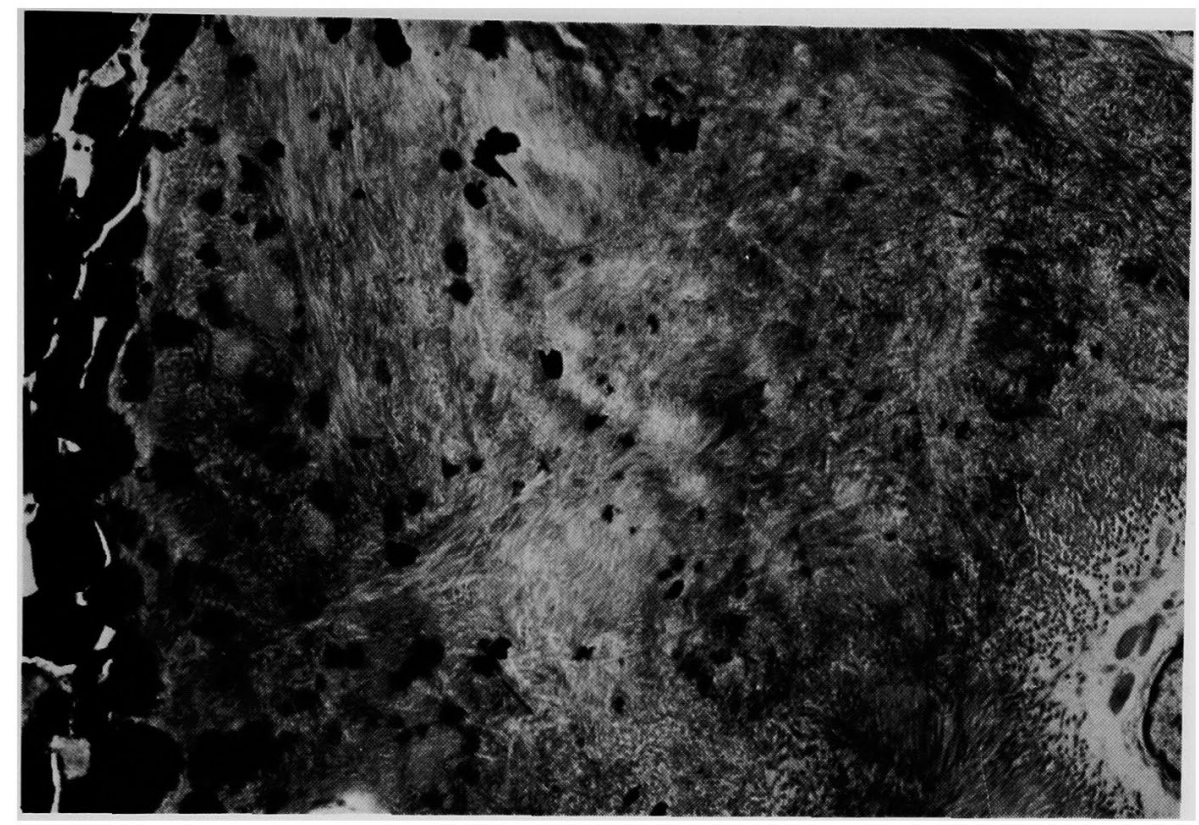

図2 アパタイト表面に形成された骨前質 $(\times 9,200)$

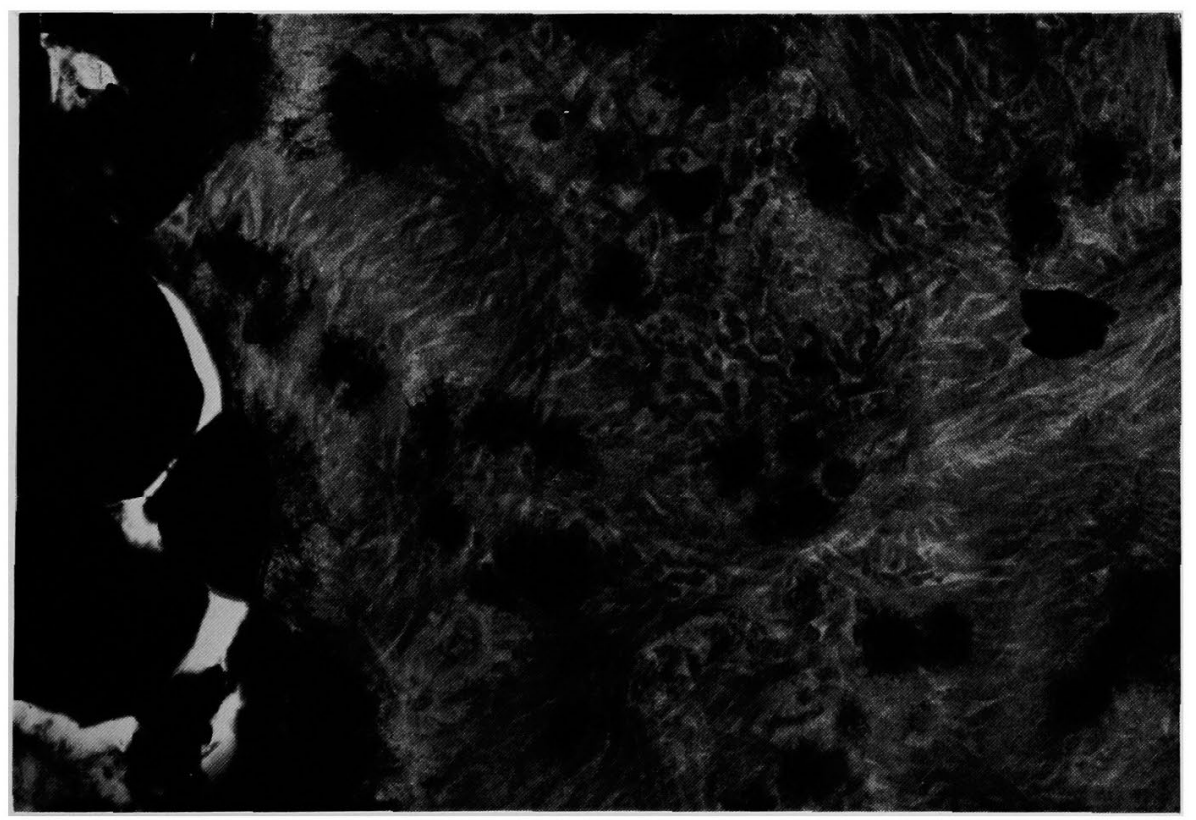

四 3 骨前犋の中でもアパタイト表面側から結晶沈着が開始される $(\times 21,800)$ 


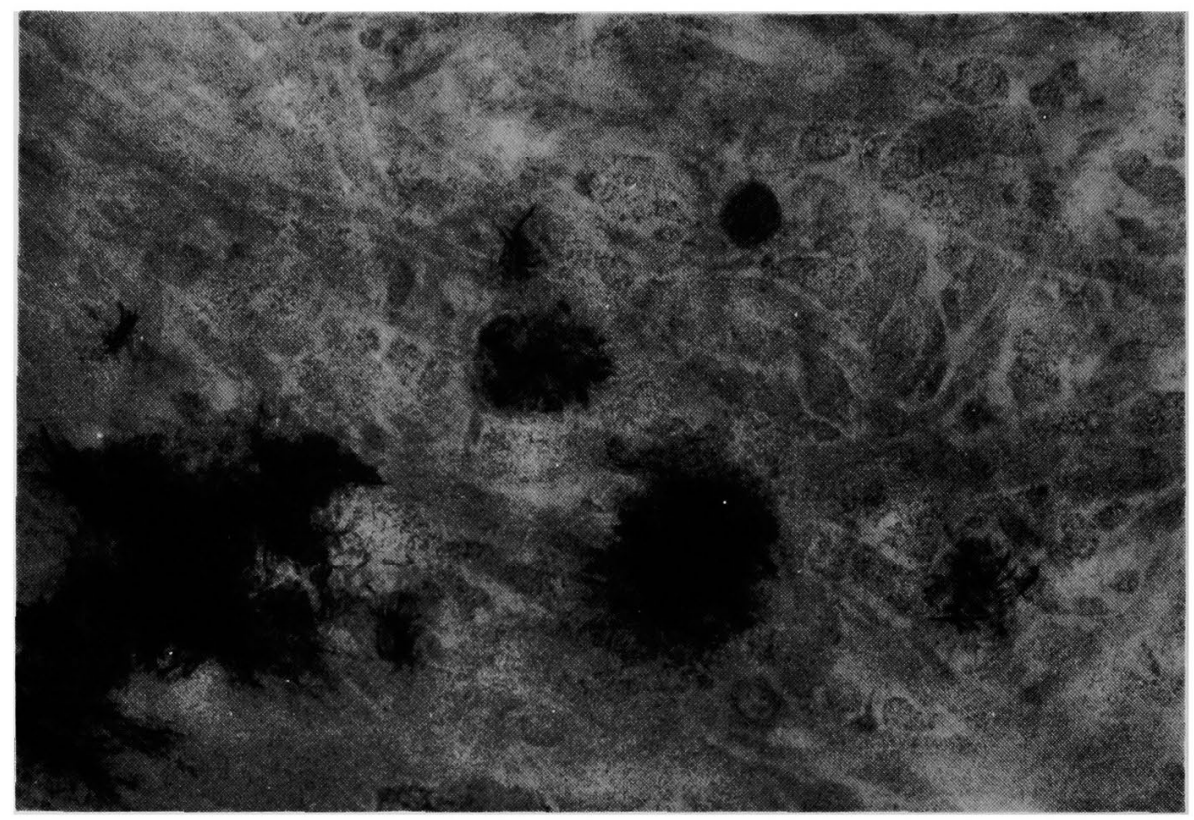

図４Collagen 線維間にさまざまな状態の基質小胞が認められる $(\times 69,600)$

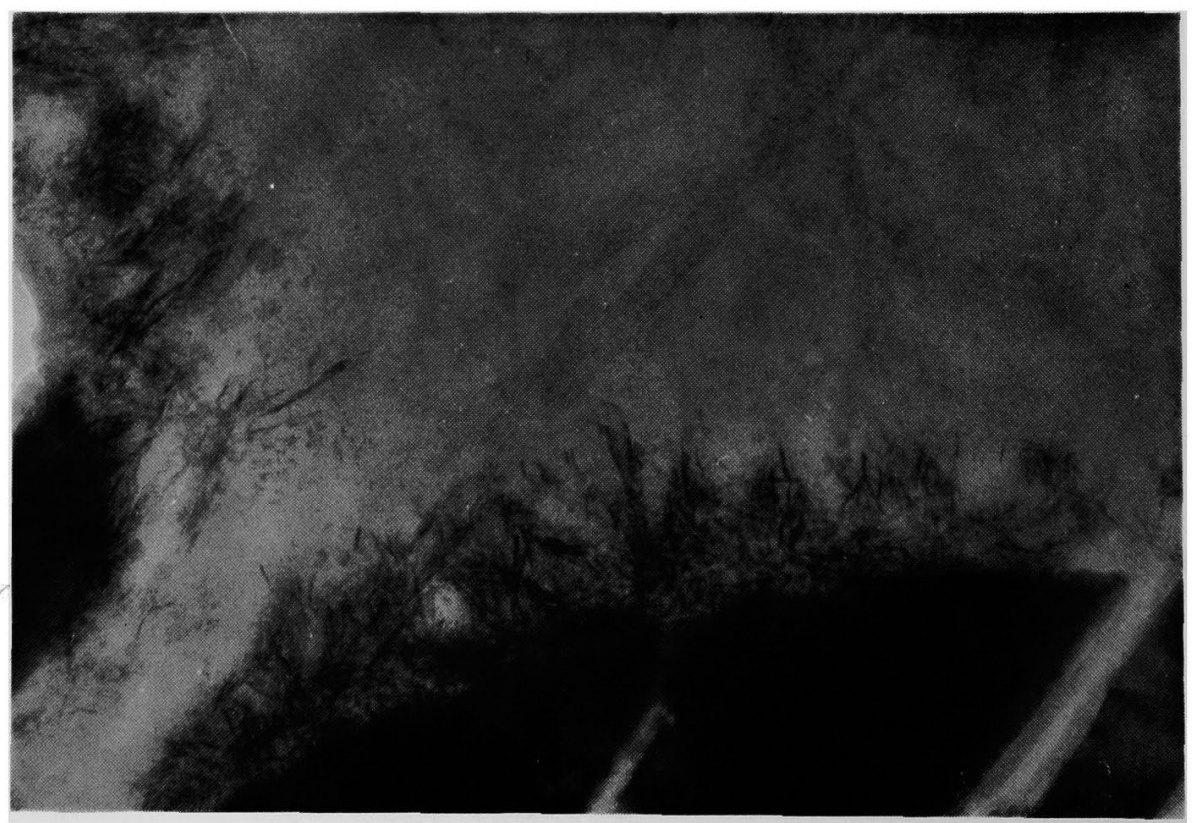

図 5 アハタイト表面に細長い板状結率が㨁接形成され始めている $(\times 126,500)$ 


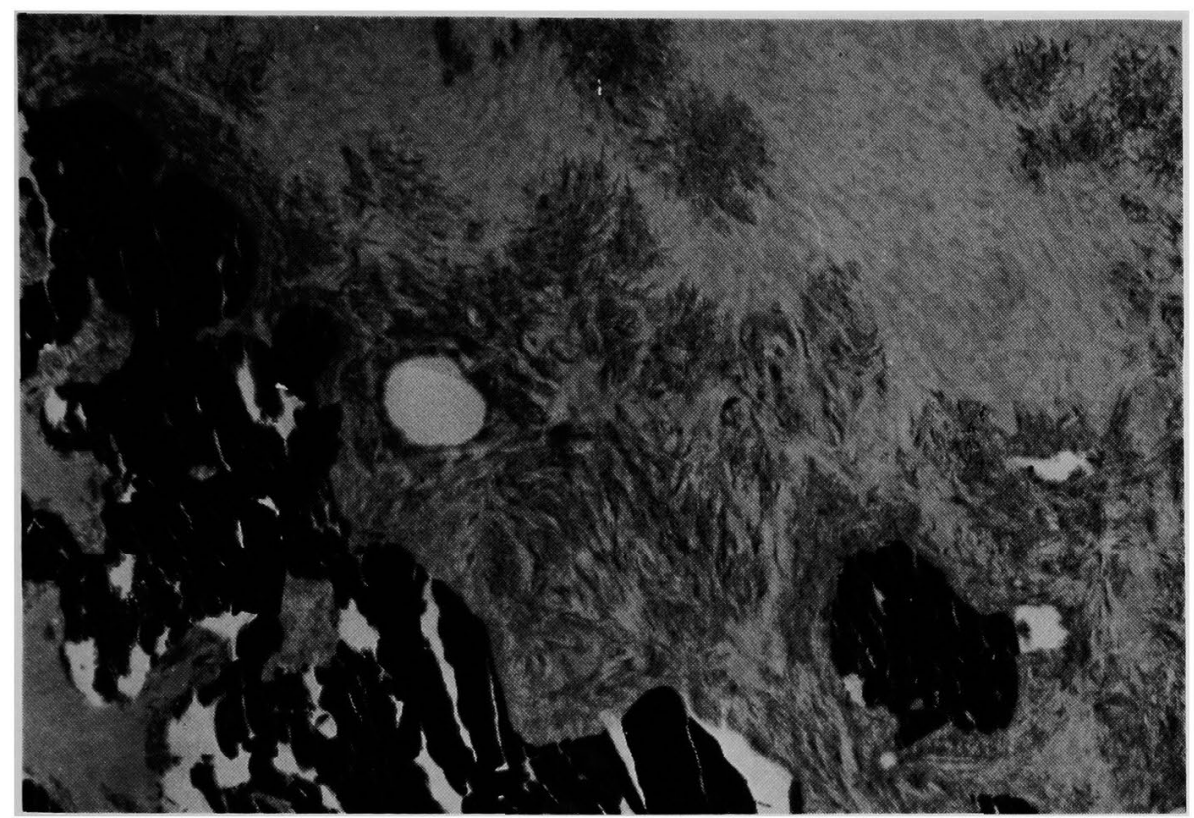

図 6 基質小胞を基盤とした結晶沈着域と，アパタイト表面を基盤とした結晶沈着層が 一体化している $(\times 14,700)$

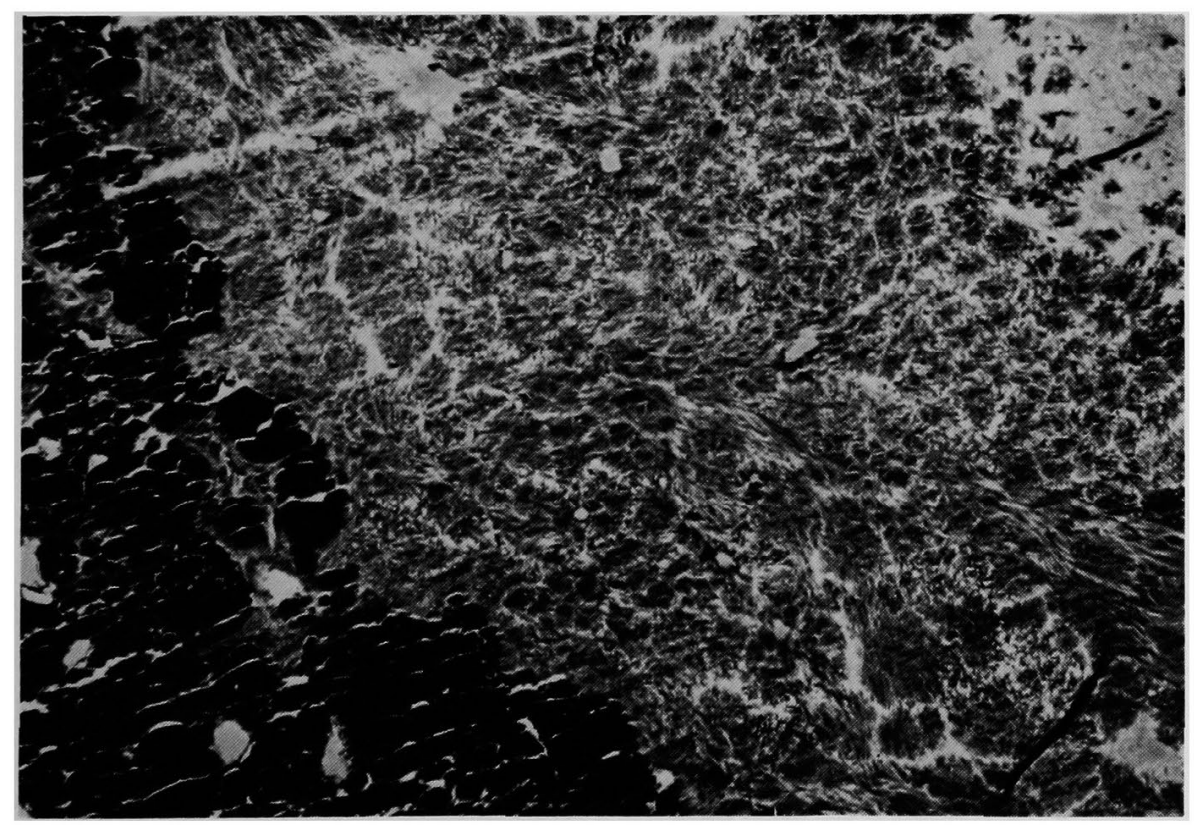

図7 埋入後10日。結晶沈着頒域が搪大している $(\times 5,200)$ 


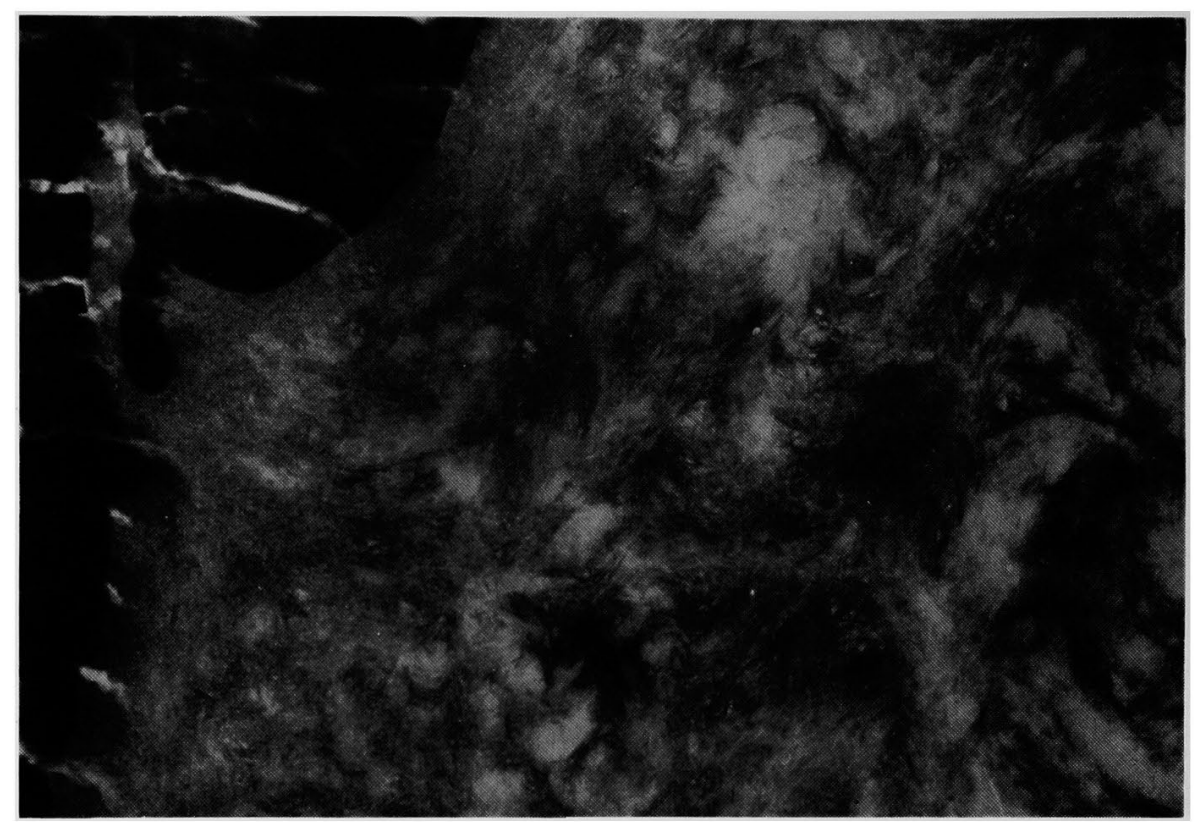

図 8 埋入後 10 日。アハィイト表面の挔人。骨結晶の状態はいまだ幼若である $(\times 43,400)$

れ，破骨細胞の出現は少ない([以]24)。

アハタイトが海綿質に埋入されている領域にお いても，アハタイト表面に形成された骨組織や, アハタイト周囲の新生骨梁は全般に発育肥厚して いる。しかしながらアハタイト周囲の 新生骨梁 は, 緻密質領域と異なり, その尘面に破骨細胞が 数多く出現し, 各所で骨吸収が進行している。し たがってアパタイト周罒に拈ける新生骨梁は, 前 段階に比して発育肥厚する一方, 骨梁間隙は拡大 している。アハタイト表面に形成されている骨組 織表面には破骨細胞はほとんどみられず，一般に は骨芽細胞が密に配列している(汹25)。

またアパタイト表面に形成された骨組織を透過 電子頙微鏡で観察すると, 骨結晶の状態は埋入後 10日の状態に比較してかなり発育しているのが認 められる(図 9, 10)。

\section{4. 埋入後30日}

アハタイト表面㧍よびその周囲に拈ける骨組織 形成は, 埋入後14日の状態に比してさらに進行 し、アハタイトが緌密質に埋入されている領域で は, 元来の緻密質切削面とアパタイトとの間隚に
扣いて新生骨組織が発育肥厚し，すでにハバース 管の形成が多数認められる。しかしながら,これ らの骨組織にはいまた比較的大きな骨髄腔が数多 く残存しており，通常の緻密質の状態にはいたっ ていない(図26)。

アハタイトが海綿質に埋入されている領域で は，アパタイト周囲に形成されている骨梁恃埋入 後14日の状態に比してその太さがわずかに増加し ている反面, 骨梁間隙が全体としてさらに拡大さ れている(図27)。骨梁間隙の拡大はとくにアパタ イトから離れた領域で早く進行している。アパタ イトに近接する部分ではそれはど顕著でなく，骨 梁間隙も比較的狭い。場所によっては骨梁の発育 肥厚に伴い， ハバース管が形成されている部分も 認められる。またアハィタイト周囲の骨梁表面にお ける破骨細胞の出現は, 埋入後14日に比して少な くなって扮り，骨芽細胞が密に配列している。海 綿質領域に拈けるアパタイト表面の骨組織は, 埋 入後14日の状態に比してやや発育肥厚している。 アパタイト表面に形成されている埋入後 30 日 の骨組織について透過電子顕微鏡で観察すると, 


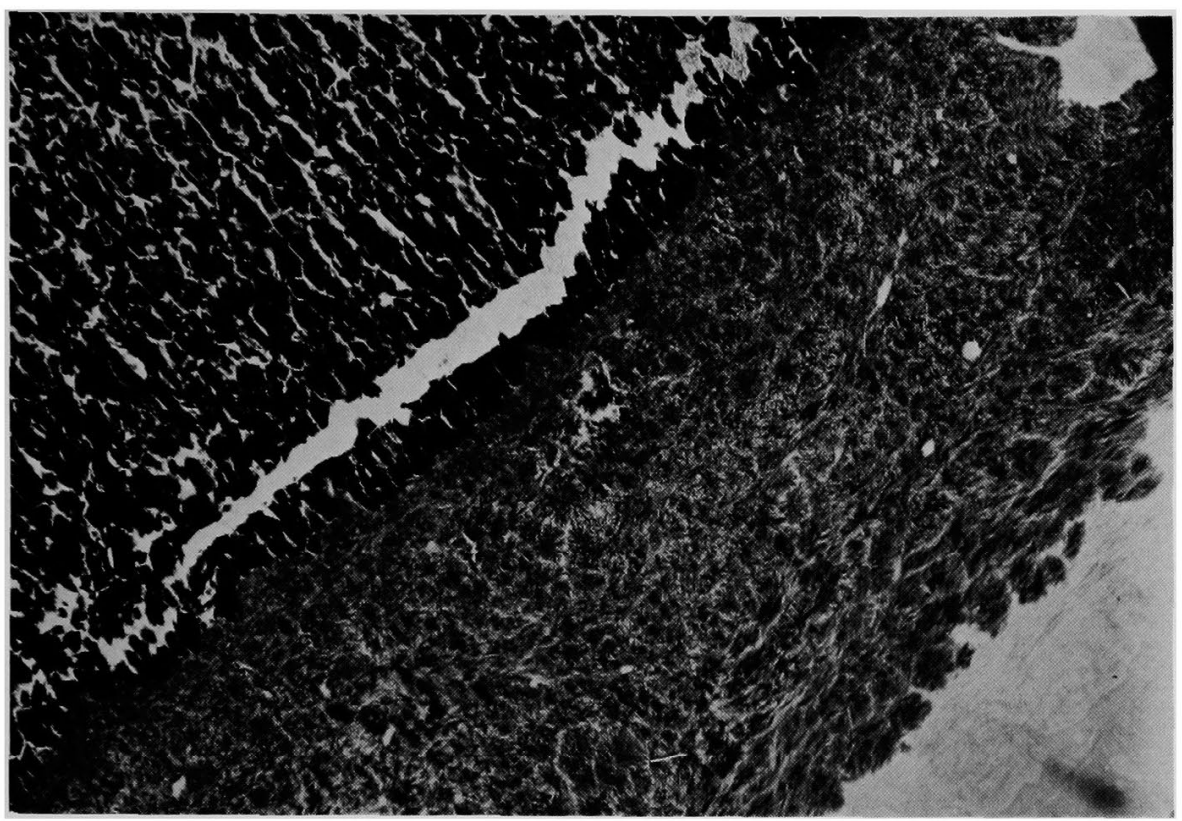

戍 9 埋入後 14 日の弱拡大 $(\times 4,000)$

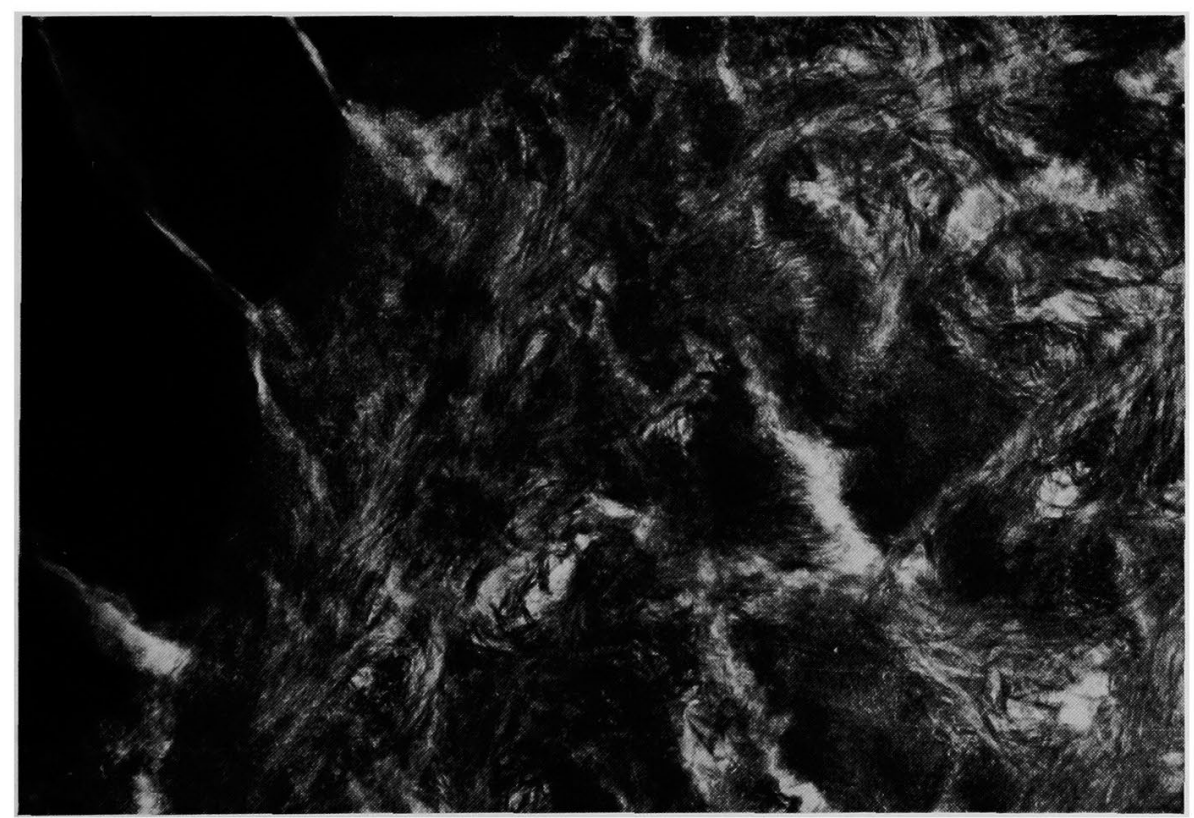

図10 埋入後14日のアパタイト表面の拡大。骨結晶の状態は埋入後10日のものより 発育している $(\times 61,100)$ 


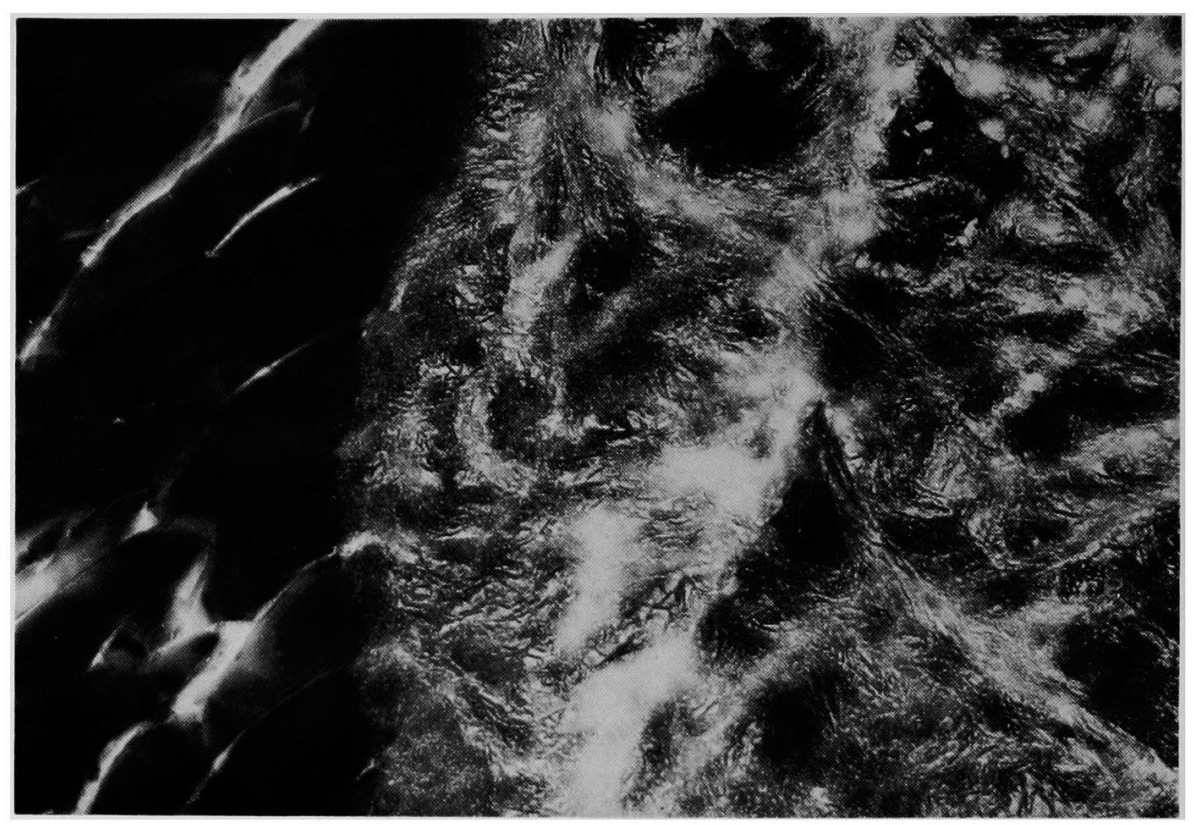

困11埋入後30日。骨結晶の状態は成熟骨のそ机とほほ同様となっている（×52,000)

骨組織内に打ける骨結晶の沈着状態は成热骨の それとほとんど差がみられなくなっている（閁 11)。

\section{5. 埋入後60日}

緻密質領域に拈いては，アパタイトと緻密質切 切削面との間隙における骨組織の形成が埋入後30 日の状態に比してさらに進行し，それらの間隙内 では間隙の広狭にかかわらずハバース層板が発育 肥厚し，繳密質構造を備えた骨組織によって満た された状態となっている(図28)。しかしながら， これら新生骨組織内にはいまだ小さな骨髄腔が残 存している。

アハタイトが海綿質に埋入されている領域で は，アハタイト周囲に批ける元米の太い骨梁に骨 組織が新生添加され，それらがアパタイト表面に 直接接している状態を除き, 術後新たに形成され た骨梁はほとんど吸收消失されている(図29)。乙 かしながら、アパタイト北面には比較的厚い一層 の骨組織が形成されて拈り，とくに太い骨梁がア ハタイトに接している部位の近辺では，アハタイ 卜表面に沿って厚い骨組織が形成されている。
これらの骨桨および骨組織表面では骨前質の幅 が減少して抢り，さらには消失している部分も認 められる。な拈骨前質が観察されても，それらの 表面にはすでに骨芽細胞が消失し，偏平な細胞や 造血細胞が接している部分も認められる。破骨細 胞もほとんど観察されない状態となっている。ま たアパタイト周囲の骨䯣組織には脂肪細胞が出現 し始めてきている。

相対密度の低いアパタイト表面部を透過電子顕 微鏡で観察すると、アパタイト表面から内方に向 かって骨組織が侵入形成されている状態が認めら れる(図12)。

\section{6. 埋入後120日}

緻密質領域では骨組織の形成が埋入後60日の状 態よりさらに進又，アパタイトと緻密質切削面と の間陌は通常の緻密質によって満たされた状態と なっている(図30)。

海綿質領域におけるアパタイト周柬の骨組織の 状態は, 埋入後60日の状態と同様アパタイト表面 に骨梁が各所で接しておりりそのような部位の近 傍に尔けるアパタイト表面には厚い骨組織が形成 


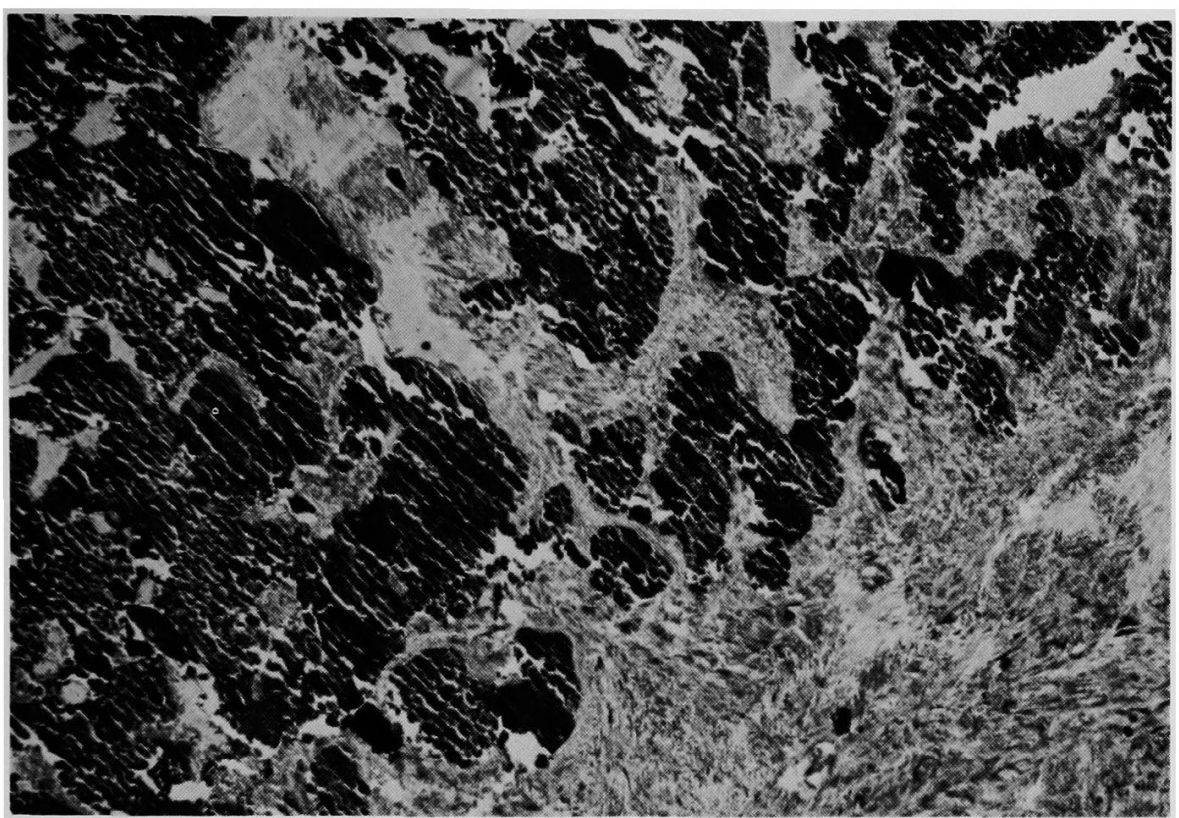

図12 埋入後60日。低密度》パタイトの場合, 表面から浅い気孔内に合か形成され, 比較的深い気孔においてもその壁に結晶沈着が認められる（×4,200）

されている。アパタイト表面に骨梁が接していな い部分においても一層の骨組織が形成されてお り,それらの骨組織は埋入後60日のものよりやや 発育肥厚している。しかしながらこの時期にいた ると，骨組織表面には骨芽細胞が注とんど観察さ 就な。

またアハタイト周囲の骨䯣は，すでに通常の海 綿質之同様，黄色骨髄となっている（四31）。ア パタイト表面近傍に形成されている骨組織を透過 電子顕徽鏡で観察すると，その構造は通常の緻密 質のそれと全く同様な状態となっている(図13, 14)。

\section{7. 埋入後410日}

緻密質領域に拊けるアハタイトは通常の緻密質 によって包文込まれて拈り,これらの状態は埋入 後120日の状態と全く同様である。

海綿質領域においてては, 埋入後 120 日の幖本と 同様アハタイト表面のほぼ全周に一層の骨組織が 形成されており，それら骨組織は各所で骨梁と速 絡している。しかしながらアパタイト表面に形成
されている骨組織は, 埋入後 120 日のものと比較 してその幅がやや細くなっている(図32)。またア ヘタイト周囲の骨髄ではその一部に, アハタイト の相対密度にかか和らず，脂肪細胞間に微細なア ハタイト結晶をとりこんだマクロファージが観察 されることがある(四33)。

アバタイト表面の骨組織は透過電子顕微鏡で観 察すると，埋入後 60 日のものと全く同様，通常 の成熟骨の状態となんら差異が認められない（図 15)。

\section{4. 考察}

従来よりインプラント材料の開発は, 材料の組 織親和性が良好で，異物反心をひきおこさないこ とを目標として進められている。しかしながらそ れらの材料の多くでは, 骨内に埋入された場合, 材料周囲に線維性結合組織の被膜が形成さ机るこ とが知ら机ている。

このよらな材料周网における線維性被膜の形成 は, 骨組織による異物反応の結果であると考兄ら 


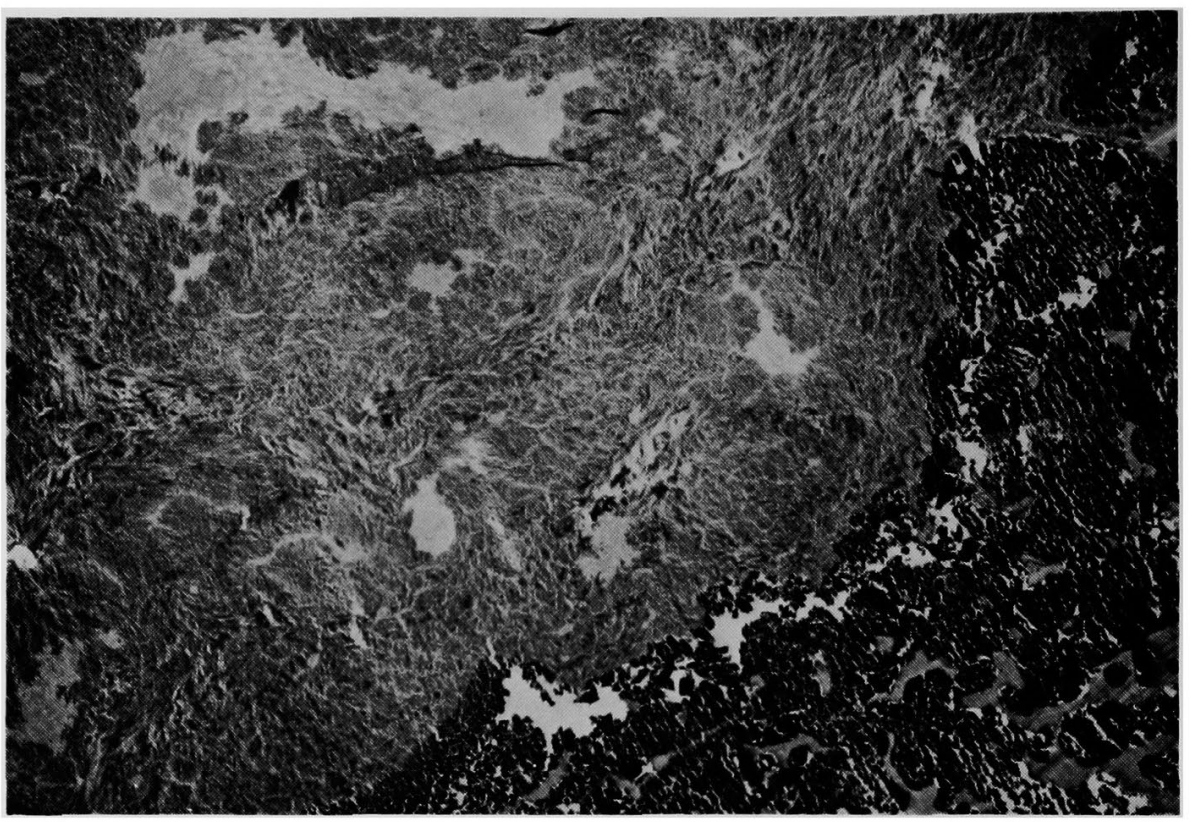

図13 埋入後120日。アパタイト表面に形成された骨は通常の成熟骨と全く同様である $(\times 2,300)$

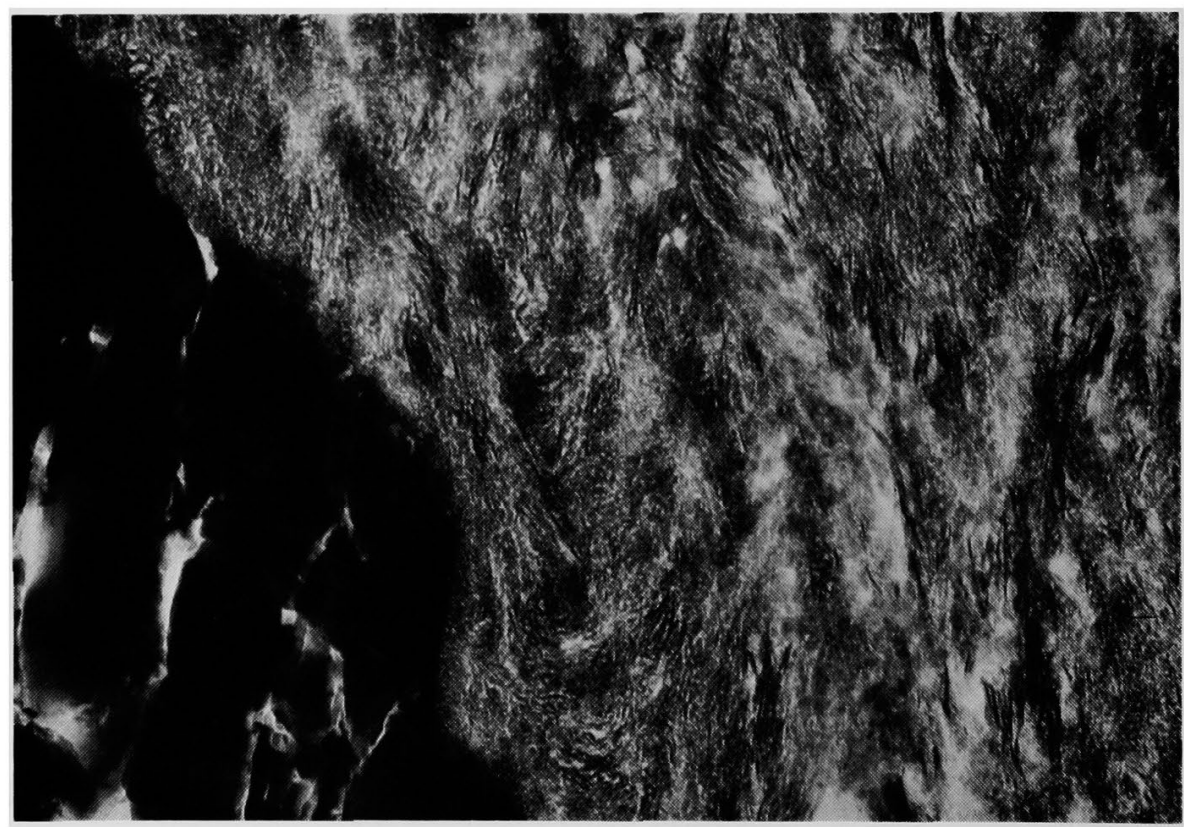

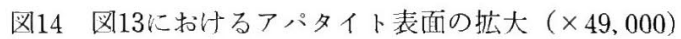




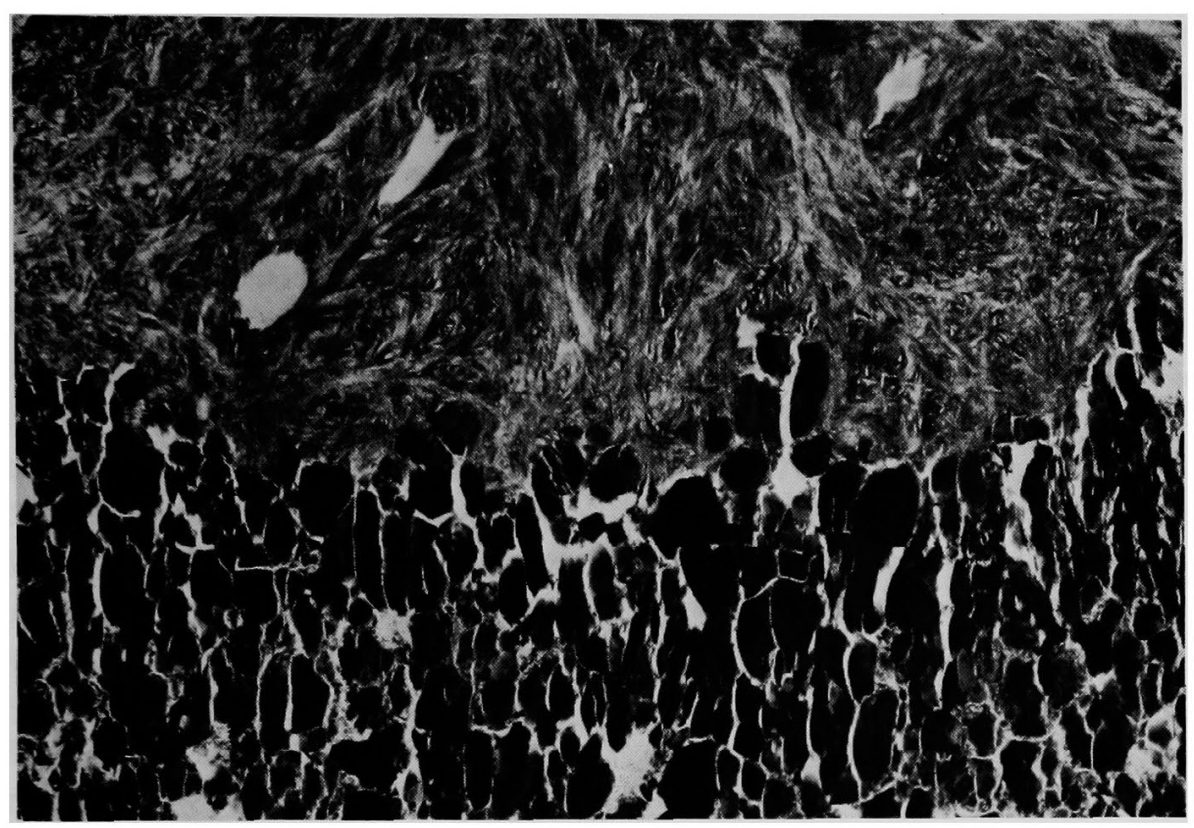

図15埋入後410日 $(\times 5,600)$

れるが，たとえこれが異物反応の結果生ずるもの ではないとしても, 線維性被膜の存在は Hulbert ら ${ }^{19)}$ が記載しているよらに, 埋入材料の動摇や周 囲骨組織の吸収の原因となると考えられる。また デンタル・インプラントの場合, 埋入材料の動摇 は口腔内から顎骨組織への細菌感染を誘い,イン プラントを不成功に終わらせる原因であるとも考 えられる。

インプラント周囲に形成される線維性被膜に対 して, 一部の 研究者は臨床的立場から pseudoperiodontal membrane ${ }^{20)}$ と呼んでいるが，当然 のことながらこの組織は天然歯周囲の歯根膜とは 全く異なるものであり, 機能的意義を認めること はできない。

以上のようなことから，最近10年間に骨組織と 結合することを目指寸材料の開発研究が進久，現 在では骨と直接結合する材料として Hench ${ }^{22}$, Clark ら) による Bioglass, Strunz $5^{5)}$, Bunte

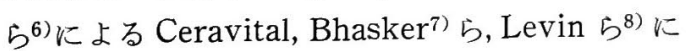
よる TCP, および 小木曾 ${ }^{10)}$, Jarcho' ${ }^{15)}$, Denissen と de Groot ${ }^{17)}$ らによるアパタイトの 4 種が報告
されている。

\section{Bioglass}

Greenlee ら1)によるとラット大腿骨に Bioglassを埋入した場合，術後 2 週では新生骨との 接触がみられ寸４週になると新生骨との接触が 認められたと記載している。この Bioglassを用 いた垁験の場合には，著者が用いているアパタイ トと比べて, 新生骨との最初の接触時期がかなり 遅い結果となっている。Clark ら) はラット脛骨 に Bioglass を埋入し， 5 週後新生骨との接触界 面を透過電子顕微鏡を用いて観察した結果，骨組 織と Bioglass との間に 2, 000 3,000A の amorphous 層があると述べている。また Hench ら も同様な実験を行い，両者の間に $800 \sim 1,000 \hat{A}$ の amorphous 層を観察し，この amorphous 層は Bioglass からのシリカを主体としたゲル層で, Bioglass と骨組織を强固に結合させる層である と説明している。しかしながら，生体内でのこの ようなシリカを主体としたゲル層や Bioglass 自 体の安定性の問題, さらにゲル層の表面に骨組織 が形成される過程については不明な点が多い。 


\section{Ceravital}

Ceravitalは Bioglass を改良したものである。 Strunz ら ${ }^{5)}$ はブタの下顎骨に Ceravital を埋入 し, 術後 5 日から 5 力月にいたる組織学的観察を 行っている。それによると術後 5 週以上経過寸る と新生骨が材料表面に接触し， 3 力月にいたると 材料周用の骨組織は層板構造をとるようになると いう。しかし骨組織と Ceravital との間に giemsa 漼に青く濃染する幅数ミクロンの層がある ことを観察している。Bunte ら ら) $^{6}$ 骨組織と Ceravital との間に観察される giemsa 液に强染す る数ミクロンの層は, bioactive な層であると説 明している。しかしながら、この bioactiveな層 とはどのような組織满造からなるものであるの かまたどのよらな経緯で骨組織が表面に形成さ れるのかについては説明さ机ていない。

\section{Tricalcium phosphate}

TCP は一般に多孔体として用いられ，骨置換 材つまり biodegradableな材料として研究が進め られている。Bhasker ら゙は骨組織が休村に们接 接寸る領域がある反面, 破骨細胞椂多核細胞に上 り吸収が行わ机ている領域もあることを認めてい る。他の研究者達8,9) も泳同様の所見を述べて おり，さらに最終的には材は䯚内で消失するこ とを認めている。しかしながらこの材料の消失 が多核細胞だけによる吸収なのか，体渡によって も溶解寸るのか否かについては明らかにされてい ない。また骨内において本材が消失する時期に関 しても研究者によってかなり差がある。著者 ${ }^{10)}$ アパタイト埋入実験において，焼結性の低い場合 にはその表面に多核細胞が出現する部分があり， 焼結性の高い場合には多核細胞はほとんど出現し ないことを観察している。すなわちアパタイトの 化学組成に近い TCP の吸收・消失において, そ の焼結性が重要な因子ではないか上考えられる。 いずれにしても，材料の一部分が骨組織と任接絬 合しているにせよ，他の部分が吸収，消失される ような材料はデンタル・インブラント材料として は好ましくないとい光る。

以上のごとくいずれの材料を用いた研究におい
ても，材料表面に骨基質が形成され石灰化してい く過程や, 生体内での材料自体の変化の有無, さ らには最終的に材料表面に形成される骨組織と通 常の骨組織との比校娭討などがなされていないた め，それらが真にインプラント材料として適して いるか否かを立証する根拠は乏しい。

著者はアハタイトが顎骨組織に対して親和性が

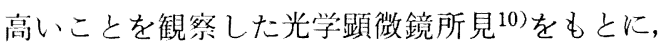
今回それらの根拠をさらに追及するためアパタ イト表面に打ける骨組織の形成過程，ならびにそ れに伴って生ずる界面領域の結晶形成状態につい て，主として透過電子顕微鏡を用いて観察を行っ た。

\section{4. アパタイト}

1）埋入後 3 日および 5 日の標本

アパタイト周罒での骨組織の形成は埋入後 3 日 では全くみられない。埋入後 5 日にいたるとアパ タイト周間での組織分化が進行するにつれ，元来 の骨梁周罒から幼若な新生骨梁がアハタイト表面 に向かって形成されるようになり，それらの一部 がフハタイト炒面にまで達するようになる。アパ タイト周网にこの上らな新生骨梁が形成され始め ると, アパタイト表面においても骨芽細胞が分化 を起こし，骨組織の形成が開始される。

しかしながら、これらアハタイト表面の骨組織 や近傍の骨梁はトルイジン・ブルーによって薄青 く染色されることから，いまだ骨基質を構成する 膠原線維の密度が低く石灰化も生じていないこと が理解される。著者ら ${ }^{21)}$ はまた, 多孔質のアパタ

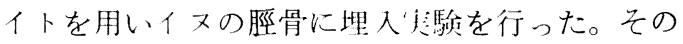
結果では, 海綿質領域では 5 日ですでにアハタイ 卜夜面に石灭化を起こした骨組織の形成が観察さ 机る。こ机はアハタイト周囲の組織分化が, 顎骨 の場合よりも脛骨の海綿質の方が早く進行した結 果によると考えている。

いずれにしても，アバタイト表面の新生骨との 接触および骨組織の形成は埋入後 5 日で開始され るのに対し，Bioglassをラットの大腿骨に埋入 したGreenlee ら゙）の実験によると，埋入後 2 週 ではいまだ新生骨との接触はみられないと述べて 
いる。また Ceravital をブタ下顎骨に埋入した Strunz 55) の実験では, 術後 5 週以上経過する と, 新生骨が材料表面に接すると報告されてい る。こ扎らの実験結果では, 埋入時トゥーリング によって生ずる熱傷などの原因による遅れも考え られるが，材料表面に骨組織の接触する時期は著 者らの所見と比較して，実験動物のちがいがある にせよ明らかに遅い。

著者が用いたアパタイトでは，その周囲に新生 骨梁が形成され始めると，ただちにそれらの骨梁 の一端がフパタイトに直接接するとともに,さら にその部を中心としてアパタイト表面で骨芽細胞 が分化を起こし，骨組織の形成が始まる。このよ らに新生骨梁がアハタイト表面に達すると, アパ タイト表面では骨原性組織が比較的早く分化を起 こしている。

以上の結果からみて, Greenlee が用いた Bioglass ならびに Strunz が用いた Ceravital に比 して,アパタイトの骨組織に対する親和性は優る とも劣らないとい光よう。

2）埋入後10日の䧣本

アパタイト周囲における組織分化は埋入後 5 日 の状態に比してかなり進行し、アパタイト周囲に 網目状の新生骨梁が密に形成された状態となる。 とくにアパタイトの焼結性が高い場合には, 緻密 質領域, 海綿質領域ともにその表面のほほ全域に 骨組織の形成が認められる。アパタイト表面に形 成された骨組織はトルイジン・ブルーによる染色 性が場所によってかなり異なることから，アハタ イト表面に形成された骨組織は, その石灰化の程 度がかなりさまざまな状態にあると考えられる。 このような骨組織を透過電子顕微鏡で観察する と, 骨組織の形成が最も遅れている部分では埋入 後 5 日の所見と同じく collagen 線維がい京だ粗 な状態で観察される。

骨組織形成がやや進んでいる領域では, アハタ イト表面に collagen 線維が密にしかも幅広く形 成されている。これら collagen 線維間にはほほほ 球形に結晶が沈着した部分が多数出現しており, さらに基質小胞も多く認められる。
これらの基質小胞はその内部に結晶の沈着が認 められるものと認められないものとがあり, 後者 に打いてもその内部の電子湾度は種々の状態で観 察される。また球形に結晶が沈着した部分の周罒 に, 限界膜が部分的に認められるものがあること などから，基質小胞と結晶沈着物とは関連がある ことが想像される。

通常の骨組織に拈ける初期石灰化の基盤は, 主 として基質小胞であることがすでに明らかにされ ている22)。アパタイト表面に形成された骨基質 は, 通常の骨組織における石灭化と同じ機序で石 灰化が始まっているといえる。

アハタイト表面周囲の骨基質にこのような結晶 沈着が始まると, アパタイト表面上にも直接結晶 が形成され始める。これらの結晶はアパタイト表 面近傍の collagen 線維とは無関係に形成されて いる。すなわちアパタイト表面周网に形成された 骨基質は通常の骨組織形成と同様, 基質小胞など を基盤として結晶が沈着し始めるのに対し，アパ タイト表面においてはアパタイトを基盤に結晶が 形成され始める。このようなことから、アパタイ 卜面に最初に形成される結晶はアパタイトと epitactic な結合をしているのではないかと思われ る。

以上のよらな部分より石灰化がさらに進行して いる部分では, 前述した球形の結晶沈着やアパタ イト表面の結晶形成部から，その周囲の collagen 線維に㳂ってさらに結晶沈着が進行することによ り,アパタイト表面に幅広い結晶沈着層が形成さ れている。

またアパタイト表面には，微細な結晶がとくに 密に沈着した幅の狭い層が観察される場合が多 い。これは術後 5 日の所見および䦷 5 で示すよう に，アパタイト表面には必ずしも collagen 線維 が接しているとは限らず，また近接している場合 でも，それらの密度がアパタイト良面からやや離 れた領域における骨基質の collagen 線維密度に 比してかなり低い場合が多く，そのよらな部分で ま寸゙最初にアハタイトに接して結晶が密に析刐し 始め,やがて元の周湖を满たすように結晶が密に 
沈着した結坚，形成された層である。したがっ て, その部分では密な collagen 線維に結晶が沈 着する通常の骨組織とは, 下地をなす collagen 線維が非常に少ない点で異なっている。この結晶 沈着層と通常の骨組織の構造をとる部分との境界 は明膫ではないが，それらの層が汇とんど垫めら れない部分から約 $0.2 \mu \mathrm{m}$ 幅に及ぶ部分までさまさ まである。

このような collagen 線維が粗で骨結晶が密に 沈着した層は，通常の硬組織においても観察され るものである。すなわち，田中231はモルモットの cementum pearl の形成について観察を行い, エ ナメル質圭面に最初に形成される cementum pearlには下地となる collagen 線維が認められ ず，結晶の配列方向も不規則であり， cementum pearl の厚さが $0.2 \mu \mathrm{m}$ 程度になると collagen 線 維がわずかに出現してくると述べている。また水 城 ${ }^{24)}$ はヒト下顎歯槽骨内壁の線維骨について観察 し, ヘマトキシリンに濃染するいわゆる优止線と 接合線の領域は, 結晶が均質な状態で密に沈着し ているが, collagen 線維诖全く，あるいはほとん ど観察されないと述べている。アパタト表面に 形成される collagen 線維を下地としない石灰化 層は, 形成初期の cementum pearl ゃ顎骨の休 止線, あるいは接合線にみられる構造物と同一の 結晶沈着状態を示し，アパタイト衣面にのみ特異 的に出現する物ではないことが理解される。

Denissen ${ }^{18)}$ はアパタイト表面に形成された骨 組織について, 脱灰後透過電子顕微鏡により観察 した結果,アパタイト表面に沿って電子透過性の 高い比較的無構造な層があることを記載し，この 層はその幅が $0 \sim 1.0 \mu \mathrm{m}$ であり, アハタイトと 骨組織との bonding layerであると述べている。

Denissen が述べている bonding layer は, 著者 の観察所見と比較してその幅がやや広く，また彼 が脱灰標本を用いているため結晶の沈着状態につ いては明らかではないが，おそらくそれは collagen 線維の少ない, 高度に石灭化した層に相当す るものと思われる。

埋入後10日で骨組織形成の最も進行した部分で
は, アパタイト表面に幅広い石灰化層が形成され ているが，骨組織内における個々の結晶は成熟骨 のそれに比してその長さおよび太さはいまだ幼若 である。

\section{3）埋入後14日の標本}

アパタイト周罒の骨組織の形成は埋入後 10 日の 状態に比してさらに進行し，発育肥厚した骨梁が 密に形成されるとともに, アパタイト表面にも比 較的厚い骨組織が観察される。これらの新生骨組 織はトルイジン・ブルーによる染色性が減少し, それら骨組織の石灰化がかなり進行していること がうかがえる。

また緻密質領域において，アパタイト周囲の新 生骨組織は破骨細胞によって吸収されることは少 なく, 発育肥厚することによりハバース管の形成 が数多く認められる状態になるのに反し, 海綿質 領域においてはアパタイト周囲の新生骨梁は一部 のものが発育肥厚する一方, 一部のものは破骨細 胞によって吸収をらけ骨梁間隙が拡大し始めてい る。

すなわち顎骨内に埋入されたアパタイト周囲の 新生骨組織は，埋入後14日より緻密質領域に打い ては緻密質構造に，海綿質領域においては海綿質 構造に移行し始めたものと思われる。

4）埋入後 30 日の標本

アパタイト周囲の新生骨組織の状態は, 緻密質 領域においては骨組織の形成がさらに進行し, 各 所でハバース管が形成された状態となる。また海 綿質領域においては骨吸収が前段階に比してさら に進行しており骨梁間隙が拡大されている。しか しながら一部の骨梁は発青肥厚し、アパタイト表 面に形成された骨組織もとの幅を増大させてい る。

この時期のアパタイト表面および周冊に形成さ れている骨組織のトルイジン・ブルーによる染色 性は, 元来の骨組織のそれとほぼ同様となってき ており，また透過電子顕微鏡による所見では骨結 晶の沈着状態は成熟骨のそれとほとんど差のない 状態となっている。

5）埋入後60日，120日の標本 
埋入後60日にいたると，緻密質領域においては 埋入時の骨切削面とアパタイトとの間隚における 新生骨組織はさらに発育が進及ほぼ緻密質の状態 となり，120日では全く緻密質の状態となってい る。

海綿質領域においてはアパタイト周囲の新生骨 梁は経時的に粗な状態となるとともに，一部に残 存した骨梁はかなり肥厚し，場所によっては本来 の太い骨梁心太い新生骨梁が追加され，それらの 骨梁がアパタイト表面の各所に直接接している。 アパイト表面の骨組織は埋入後30日に比してや や発育肥厚しており，とくに骨梁が接している部 分の周囲では他領域に比して骨組織形成が早く進 行している。またアパタイト周团の骨髄には埋入 後60日より脂肪細胞が出現し始め，120日にいた ると元来の骨髄と全く同様な骨髄となる。成犬の 場合には黄色骨髄となる場合が多い。

このように顎骨内に埋入されたアパタイト周囲 は, 埋入後 120 日にいたると完全にもとの状態に 復し, 埋入後の活発な治癒機転は一応終了したも のと認められる。

アヘタイト表面に形成されている骨組織を透過 電子顕微鏡で観察すると, 骨結晶の状態は埋入後 60日のものから成熟骨の状態と全く同様になって おり,その組織構造になんら異常は観察されない。

6）埋入後 410 日の標本

アハタタイト周囲にお汁る骨組織の状態は埋入後 120 日の状態と基本的に差はない。しかしなが ら，海綿質領域に扎いてはアパタイト周囲の骨梁 や表面の骨組織の幅がやや減少している。

抜歯後経時的に顎骨が廃用性萎縮に陥り, 海綿 質領域においても骨梁の数が減少するとともにそ

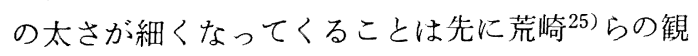
察によって報告されている。このような現象はア ハタイト周囲においても当然起こりらることであ る。

今回の観察では, アパタイトが顎骨内に完全に 埋入されて扣り, 全く無機能下の状態について行 ったものである。アバタイトに咀嚼機能が加わる 機能的負荷状態下に置かれた場合, このような顎
骨の廃用性萎縮を抑制し得るかどらかについて は, 機能的負荷状態下のア, タイト画根につい て, 今後さらに研究を進めていく予定である。

\section{7）アパタイト表面構造の安定性}

焼結性が低いアハタイトの場合, 埋入後初期の 段階でその表面にアハタイトの絬晶塊をとりこむ 破骨細胞が出現し，とくに埋入後15日ではアハタ イト表面全体の半分以上に破骨細胞が出現した状 態となる。しかしながらそれら細胞は, 光顕的に アバタイト表面の形態を変化させるほどアパタイ 卜結晶をとりこもことはなく，漸次アパタイト表 面から離脱する。やがてそれらの領域にも骨組織 の形成が開始され，埋入後60日にいたるとアパタ イト表面のほとんどが新生骨組織で被われた状態 となる。この際アハタイト表面の骨組織の形成が 進行するにつれ, 周用の骨髄内にアハタイトの結 晶塊をとりこんだ細胞が認められるよらになり， 術後 120 日以上経過しても骨髄の脂肪細胞間に上 記細胞が多数存在している。このような所見から 破骨細胞はアパタイト結晶塊をとりこんでも，そ れら結晶をすみやかには溶解消失させ得ないので はないかと思わ机る。

いずれにしてもアハタイトをデンタル・インプ ラント材料として用いる場合には，材料表面にお ける骨組織の形成の速さから，また物性の観点か らも焼結性が高いアハタイトでなければならな い。

焼結性の高いアハタイトの場合, アバタイト表 面での骨組織の形成は埋入後 5 日で始まり, 10 日 ではその全表面において認められるようになる。 埋入後60日にいたると緻密質領域においてはアハ タイト表面に緻密質が形成され，海綿質領域では 一層の骨組織に被われた状態となる。なおこの状 態は埋入後410日においてもほとんど変わらな い。以上の上うに骨内に拈けるアパタイトは埋入 当初の短期間を除き，それ以後は新生骨組織に上 って被われた状態が維持される。さらにアパタイ トを構成している結晶は，骨組織の結晶と比較し てその結晶性が高く,大きさはお扰よそ0.5 1. 0 $\mu \mathrm{m} て ゙ ， ， h \frac{h}{h}$ 結晶の大きさと比較してはるかに大き 
い。したがって顎骨内に埋入されている烍結性の 问い的流湜了ハタイトが体液によって溶解すると

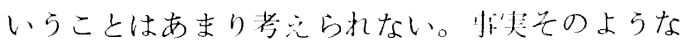
所見は钼察されていない。結論的には顎骨内に埋 入されたアバタイトは，安定した状態にあるとい 兄よう。

\section{結 論}

アパタイト表面における骨組織の形成過程なら びにその石死化について，アパタイト埋入後 3 日 から410日間経過した成犬下顎骨䧣本を用い, 組 織学的に観察を行った。

1 フハタイト㘳面に书ける骨基質の形成は，寸 でに埋入後 5 日で開始されている。

2アパイト表面上に形成される collagen 線 維の密度は, その周困に形成される collagen 線 維の密度に比して低い場合が多い。

3 焼結性が克いアパタイトの場合, 埋入後10日 でアパタト监面のほほ全域に骨組織の形成が認 められる。

4アハタイト表面に形成さ机た骨基質の石灭化 は埋入後10日で開始される。

(5)アハタイト表面に幅広く形成さ机た骨基質の 石灰化は, collagen 線維間に存在する基質小胞 などを基盤として開始される。

6アアタタイト永面においては, collagen 線維 に沿った結晶沈着が生ずる以前に collagen 線維 とは関係なく、アハタイトを基盤として結晶が形 成され始める。

(7アパタイト表面を基盤として生じた結晶層 と，基質小胞などを基盤として生じた結晶の沈着 領域は, やがて各々の周囲に存在する collagen 線維に沿った結晶沈着が開始されることにより， 連続した絬晶沈着層となる。

8アハタイト表面上には collagen 線維が比較 的粗で, 結晶密度の高い層が埋入後 410 日にいた るまで観察される。しかしこの層の幅は部位によ って差がみられ，約 $0.2 \mu \mathrm{m} に 及 ふ ゙$ 領域からほとん ど認められない領域まであって一定しない。

(9)ハタイト表面に形成された骨組織の結晶の
沈着状態は, 埋入後60日のものから成熟骨の状態 と全く同様となり，その組織樓造に拈いてもなん ら異常は観察されない。

10 埋入後60日にいたると, 顎骨の緻密質領域に 埋入されたアハタイト周围には緻密質が形成さ れ，海綿質領域に埋入されたアパタイト表面には 厚い一層の骨組織が形成され，それら骨組織が骨 梁と各所で連絡した状態となる。

(11)埋入後 410 日のアパタイト周囲の骨組織の状 態は，60日の状態とほとんど同じである。

12了ハタイトが経時的に吸収や溶解を受けてい ると思われる所見は, 埋入後 410 日にいたっても 観察されず，顎骨内に埋入されたアハタイトは安 定したものであることが認められた。

\section{謝辞}

稿安䅂えるにあたり、ご校閲怘賜りました歯学部第 2函科補綴学教室田端恒雄教授に䔆んて感謝の意它表 します。

また䅰切丁寧なご指導、ご教授をいただきました雨 学部解剖学教室一條尚教授, ならびに山下靖雄教授に 深く感謝したします。

\section{文献}

1) Greenlee, T. K., Beckham, C. A., Crebo, A. and Malmorg, J. C.: Glass ceramic bone implants. A light microscopic study. J. Biomed. Mater. Res. 6: 235-244, 1972.

2) Hench, L. L. and Paschall, H. A.: Histochemical responses at a biomaterial's interface. J. Biomed. Mater. Res. Symp. 5: 49-64, 1974.

3) Clark, A. E., Hench, L. L. and Paschall, H. A.: The influence of surface chemistry on implant interface histology: A theoretical basis for implant materials selection. J. Biomed. Mater. Res. 10: 161-174, 1976.

4) Brent, E. M. and Shapiro, P. A.: A method of obtaining an epithelial attachment on an endosseous implant. J. Prosthet. Dent. 45: 550-557 1981.

5) Strunz, V., Bunte, M., Stellmack, R., Gross, U. M., Kühl, K. and Deutscher, K.: Bioactive Glaskeramic als lmplantatmaterial in der Kieferchirurgie. Dtsch. Zahnärztl. Z. 32: 287290, 1977.

6) Bunte, M., Strunz, V., Gross, U. M., Kühl, K. 
and Deutscher, K.: Kiefer-Augumentation mit Glaskeramic in Tievesuch. Dtsch. Zahnärztl. Z. 32: 323-325, 1977.

7) Bhasker, S. D., Brady, J. M., Getter, L. Grower, M. F. and Driskell, T.: Biodegradable ceramic implants in bone. Oral Surg. 32: 336346, 1977.

8) Levin, M. P., Getter, L., Cutright, D. E. and Bhasker, S. N.: Biodegradable ceramic in periodontal defects. Oral Surg. 38: 344-351, 1974.

9) Mors, W. A. and Kaminski, E. J.: Osteogenic replacement of tricalcium phosphate ceramic implants in the dog palato. Archs. Oral Biol. 20: 365-367, 1975.

10）小木曾誠：Apatite 焼結体埋入による顎骨組 織の経時的推移变化.，口病誌 45:170-221, 1978.

11) Ogiso, M., Kaneda, H., Arasaki, J., Tabata, T. and Hidaka, T.: Epithelial attachment and bone tissue formation on the surface of hydroxyapatite ceramics dental implants. Biomaterials 1980, Edited by G. D. Winter,D. F. Gibbons, and H. Plenk, Jr., U. S. A., 1982, John Wiley and Sons Ltd., 59-64.

12) Ogiso, M., Kaneda, H., Arasaki, J., Ishida, M., Shiota, T., Mitsuwa, T., Tabata, T., Yamazaki, Y. and Hidaka, T.: Hydroxyapatite ceramics (H. A. C.) implant under occlusal function. Animal studies and clinical studies. Trans. 7th Ann. Meet. Soc. Biomater. 13th 1nt. Biomater. Symp., 1981, 54.

13) Ogiso, M., Ishida, K., Tabata, T., Yamazaki, Y. and Hidaka, T.: Clinical application of apatite implant (1) and experimental study of healing process of mucous membrane around implant. Trans. 8th Ann. Meet. Soc. Biomater. 14th 1nt. Biomater. Symp., 1982, 77.

14）小木曽誠, 田端恒雄: アパタイトセラミック ス・インプラント. the Quintessence 1: 12-16,
1982.

15) Jarcho, M., Jasty, V., Guamer, K. I., Kay, J. F. and Doremus, R. H.: Electron microscopic study of a bone-hydroxyapatite implant interface. Trans. 4th Ann. Meet. Soc. Biomater. 10th Int. Biomater. Symp., 1978, 112.

16) Jarcho, M.: Calcium phosphate ceramics as hard tissue prosthetics. Clinical Orthopaedics 157: 259-278, 1981.

17) Denissen, H. W. and de Groot, K: Immediate dental root implants from synthetic dense calcium hydroxyapatite. J. Prosthet. Dent. 42: 551, 1979.

18) Denissen, H.: Dental root implants of apatite ceramics. Vrije Universiteit te Amsterdam. 1979, Boek-en offsetdrukkerij Los-Naarden.

19) Hulbert, S. F., Richbourg, H. L., Klawitter, J. J. and Sauer, B. W.: Evaluation of a metalceramic composite hip prostheses. J. Biomed. Mater. Res. Symp. 6: 189-198, 1975.

20) Linkow, L. I., Chercheve, R. and Tones, M.: Theories and techniques of oral implantology. Volume one, Saint Louis, 1970, Mosby, 81-133.

21）山崎安晴, 大西正俊, 塩田重利, 小木曾誠, 一條 尚：人工骨としての多孔質アパタイト -1. 脛骨埋入実験一. 口病誌 $49: 251-278$, 1982.

22） Talmage, Roy, V., 小沢英浩 : 硬組織の形成と 石灰化一第10回国際解剖学会硬組織 シンポシ ウム記録一. 1978, 東京, 社会保険出版社, 9-82.

23）田中秀：モルモット臼歯の cementum pearl に関する組織発生学的研究. 口病誌 $47: 281$ $-328,1980$.

24）水城春美：ヒト下買歯槽骨内壁における線 維骨の構造に関する組織学的観察. 口病誌 $46: 65-104,1979$.

25）荒崎淳三：抜歯後における下顎骨の経時的变 化. 口病誌 $49: 358-399,1982$. 


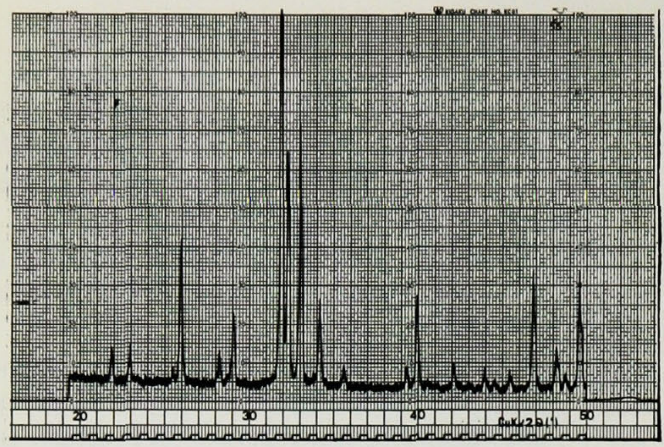

図16 実験に用いたアパタイト (Ap) のX線 回折図形。結晶性の高いハイドロキシ・ アパタイトであることを示す。相対密度 の違いによる図形の差はほとんど認めら れなかった

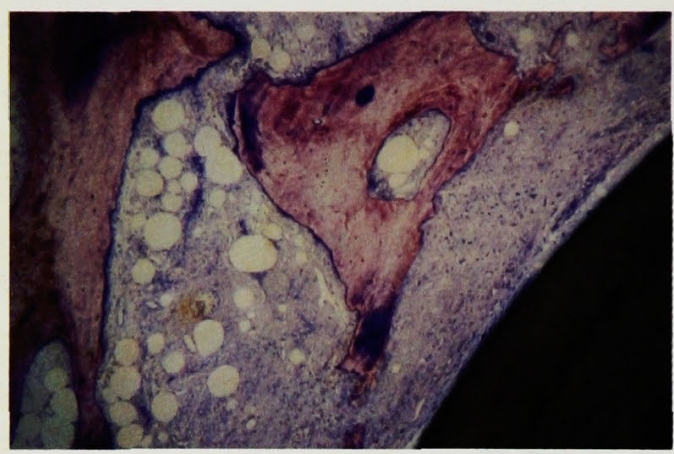

図17 密度 $95 \%$ Ap 埋入後 3 日。Ap から離 れた領域における骨表面および骨髄内で は骨基質形成が関始されている（トルイ シン・ブルー染色, $\times 20$ )

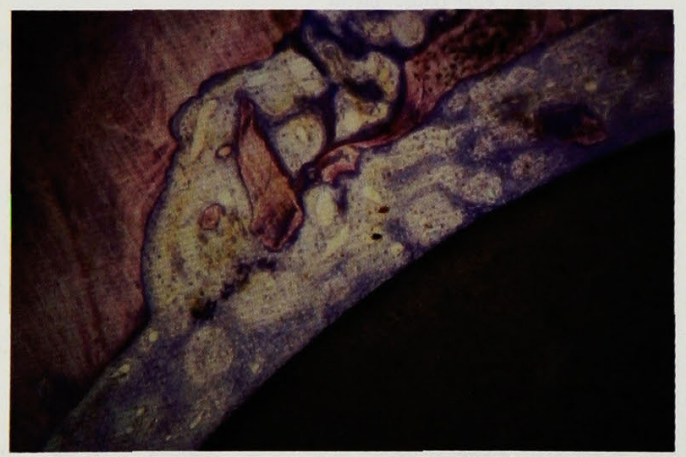

図18 密度 $95 \%$ Ap 埋入後 5 日。Ap 周囲に 網目状をなした幼若な骨梁の形成が認め られる（トルイジン・ブルー染色， $\times$ 20)

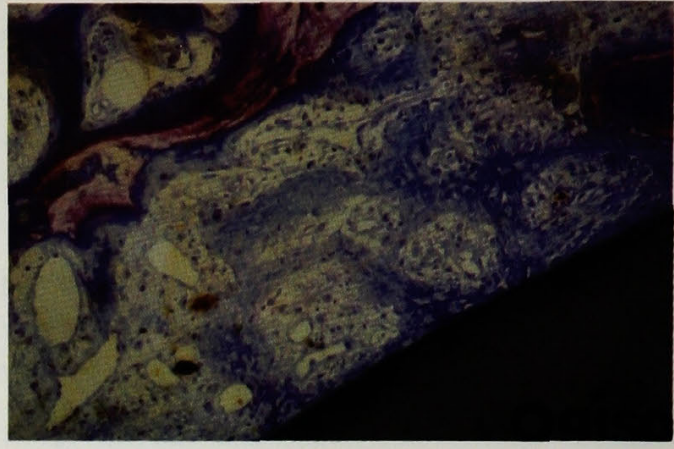

図19 図18の拡大。新生骨梁は毛細血管の周 囲に形成され，それらの一部は $\mathrm{Ap}$ 表面 に達している。また Ap 表面でも骨基質 形成が開始されている（トルイジン・ブ ルー染色, $\times 50$ )

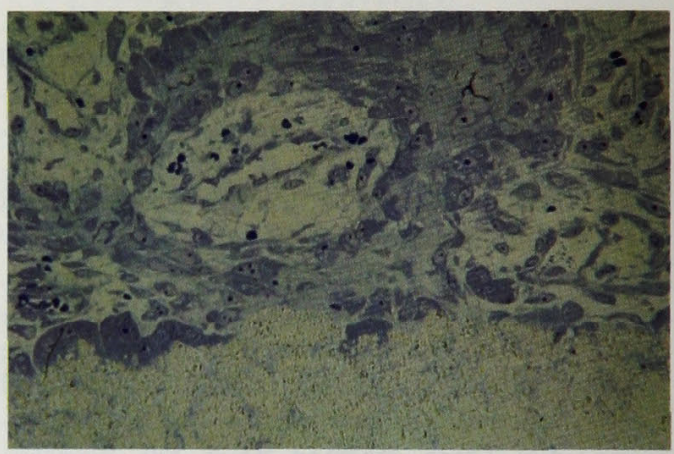

図20 密度 $56 \%$ Ap 埋入後 5 日。幼若な骨梁 の一端が Ap に達している。Ap 表面に 多核細胞が分化出現している（トルイシ ン・ブルー染色, $\times 80$ )

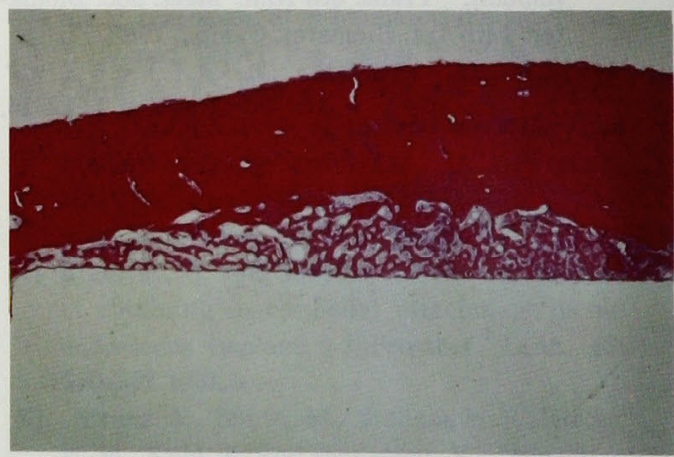

図21 密度 $95 \%$ Ap 埋入後 10 日。Ap は脱灰 により消失している。Ap 周囲では骨梁 が密に形成され，また $\mathrm{Ap}$ 表面のほぼ全 域に一層の骨組織が形成されている（へ マトキリン・エオジン染色，×5） 


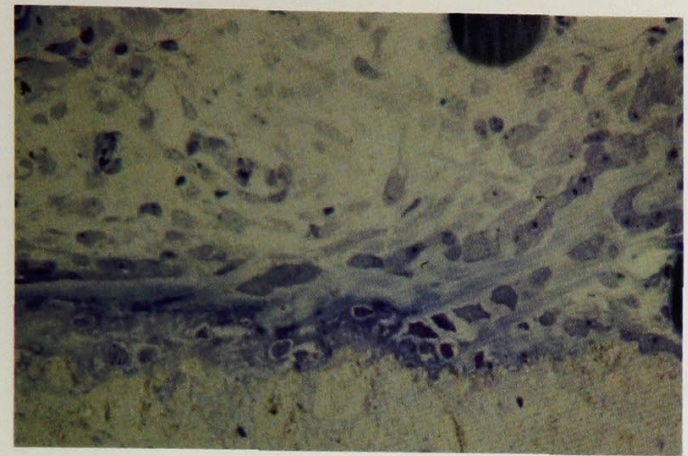

図22 密度56\% Ap 埋入後 10 日。Ap 表面に 形成された骨基質の石灰化が開始されて いる。紫に染色されている部分が石灰化 の始まった領域に相当する（トルイジ ン・プルー染色, $\times 80$ )

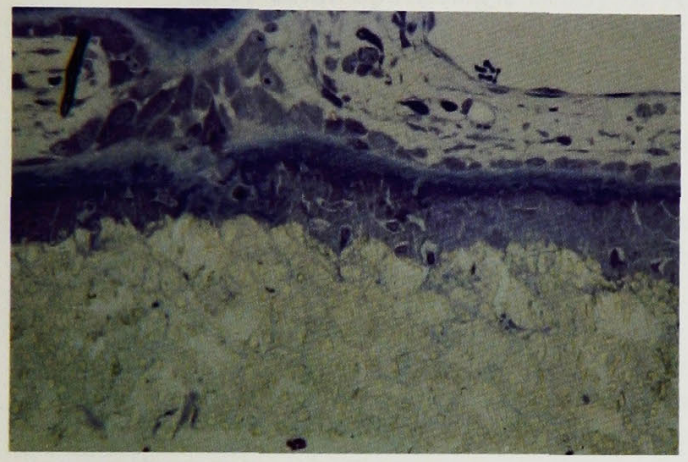

図23 密度79\% Ap 埋入後10日。骨形成の早 い領域では幅広い石灰化層が形成されて いる（トルイジン・ブルー染色， × 80)

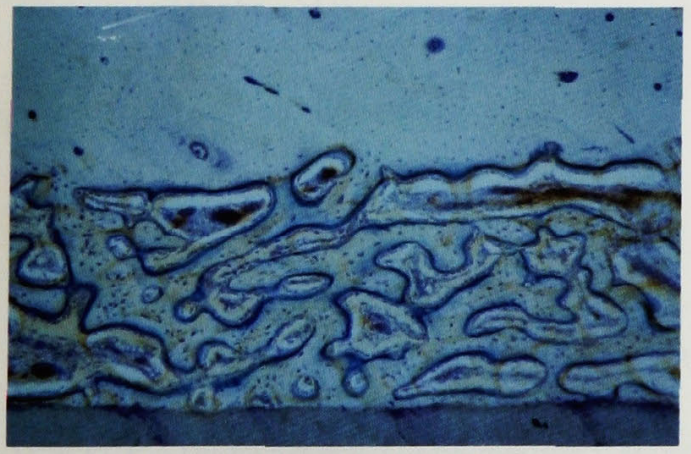

図24 密度 $95 \% \mathrm{Ap}$ 埋入後 2 週の 緻密質領 域。Ap 周因に発育肥厚した骨梁が密に 形成され，しかもその染色性は低下して いる（トルイジン・ブルー染色， × 20 , 金田氏提供)

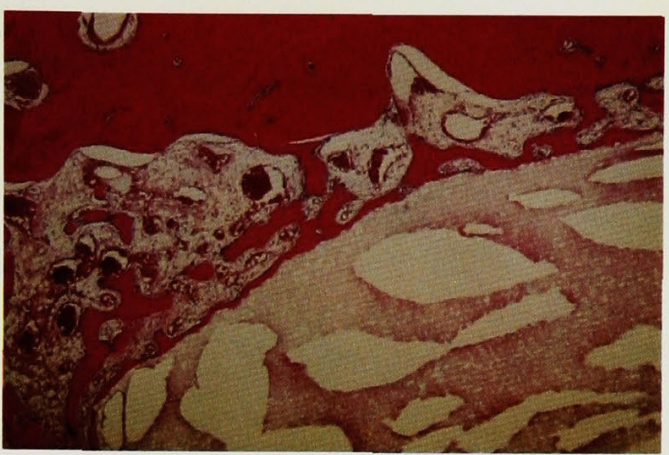

図25 密度 $68 \% \mathrm{Ap}$ 埋入後 2 週の海綿質 領 域。Ap 表面には一層の骨組織が形成さ れているが, 海綿質の新生骨梁は粗にな ってきている(へマトキシリン・エオジ ン染色, $\times 13.2)$

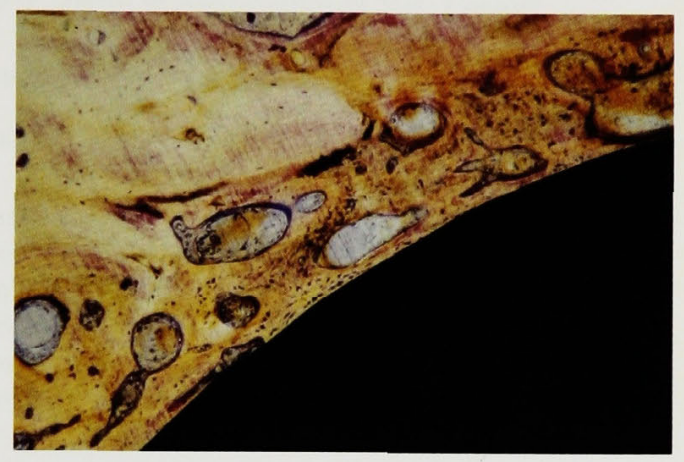

図26 密度 $95 \%$ Ap 埋入後 1 力月の緻密質領 域。Ap と骨切削面之の間隙に形成され た新生骨は緻密質構造に移行し始めてい る（トルイジン・ブルー染色， × 20）

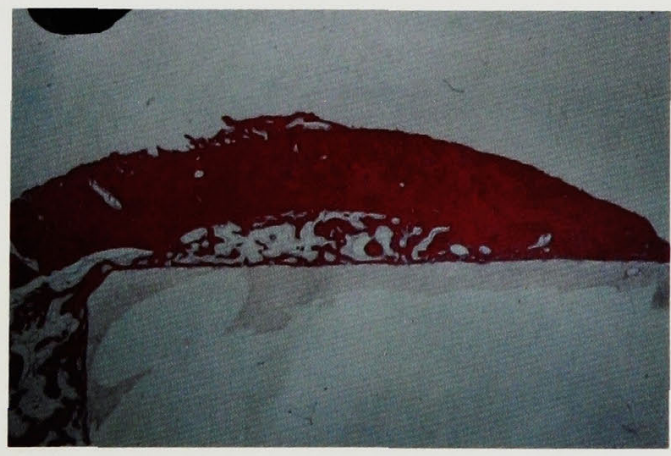

図27 密度79\% Ap 埋入後 1 力月。海綿質領 域では埋入後 2 週のものに比して, Ap 表面の骨組織が肥厚している反面, 周囲 の骨梁は減少している(へマトキシリン ・エオジン染色，×3） 


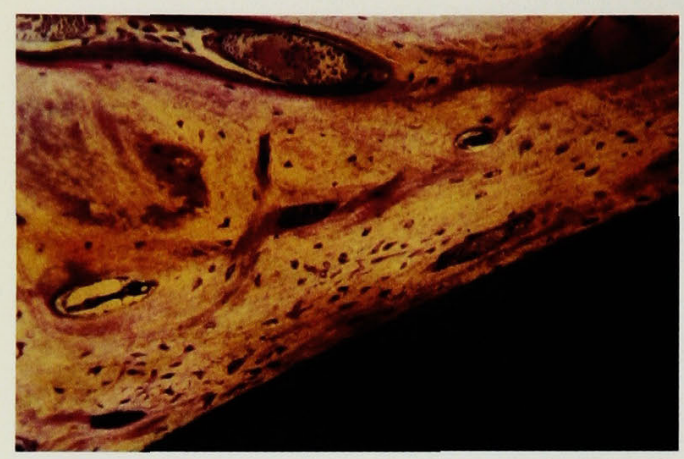

図28 密度 $95 \% \mathrm{Ap}$ 埋入後 2 力月の緻密質領 域。Ap 周囲には徵密質が形成されてい る（トルイシシン・ブルー染色， $\times 20 ）$

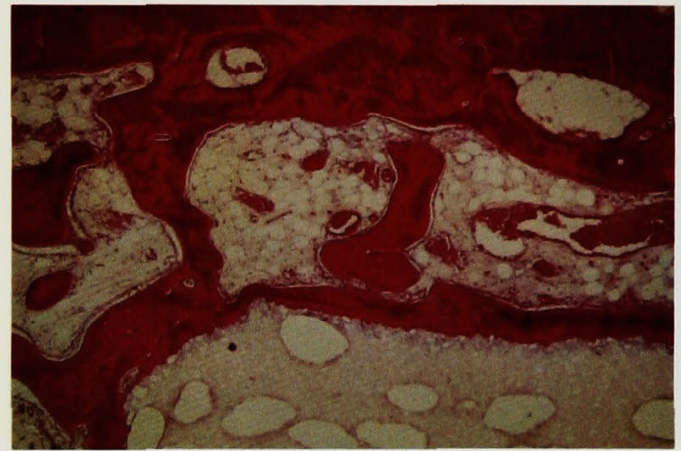

図29 密度 $68 \% \mathrm{Ap}$ 埋入後 2 力月の 海綿質 領域。Ap 表面の骨組織は埋入後 1 力月 のものより肥厚している。海綿質には太 い骨梁が粗な状態で観察される(へマト キシリン・エオジン染色， ×13.2）

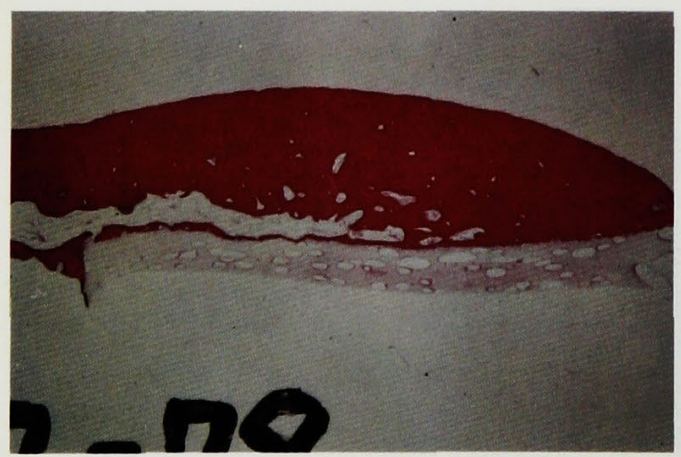

図30 密度 $68 \%$ Ap 埋入後 4 力月。Ap 周囲 の骨髄は黄色骨髄となっている(へマト キシリン・エオジン染色, $\times 3$ )

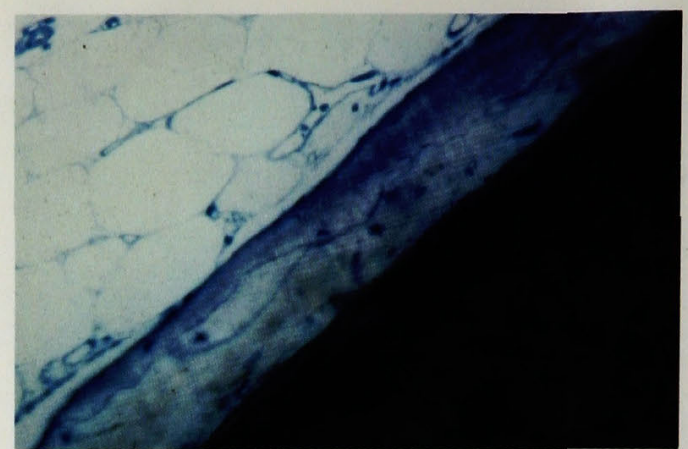

図31 密度79\% Ap 埋入後 4 力月の海綿質 領域に护ける払大。Ap を被った骨組織 表面に骨芽細胞は認められない（トルイ シンン・ブルー染色， ×66)

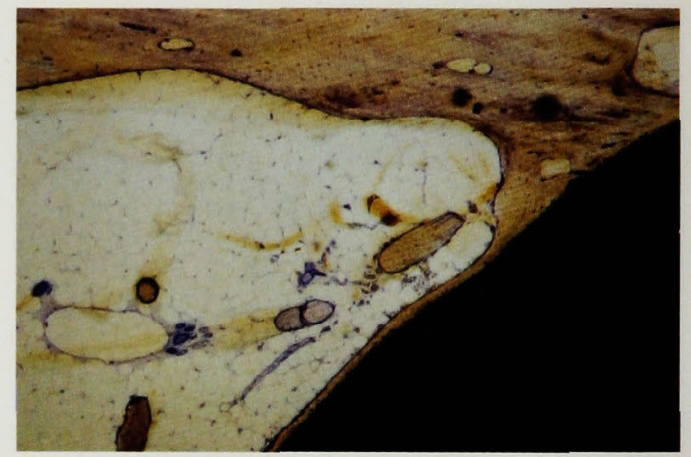

圀32 密度 $95 \%$ Ap 埋入後 410日の海綿質領 域。Ap に骨梁が接していない部では一 層の薄い骨組織が被っている（トルイシ ン・ブルー染色， ×13.2)

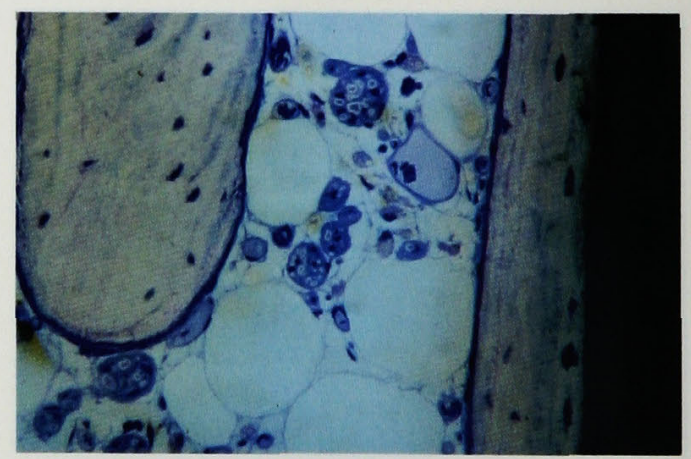

図33図32の一部を拡大。脂肪細胞間にアハ タイトの微粒子をとりこんだマクロファ ージが観察される 